\title{
PROYECTOS DE REMODELACIÓN DEL PALACIO DE CHAPULTEPEC EN LA ÉPOCA DEL EMPERADOR MAXIMILIANO
}

Michael Drewes

Pocos son los testimonios que se conocen como expresiones de la sensibilidad en las artes plásticas de la época del efímero imperio del soñado archiduque Maximiliano de Habsburgo. Adquirieron fama las Bacantes representadas en los tableros de una de las terrazas del castillo de Chapultepec, pintadas por Santiago Rebull por encargo del emperador, ${ }^{1}$ y se dieron a conocer los proyectos de remodelación del Palacio Nacional por el arquitecto austriaco C. Kaiser, trabajos que se quedaron en el boceto y afor tunadamente no se hicieron realidad. ${ }^{2}$

Ahora nos ocuparemos de las modificaciones del alcázar de Chapultepec, tanto de las que fueron ejecutadas como aquellas que se quedaron en proyecto, emprendidas durante el breve interludio del archiduque Maximiliano de Habsburgo. Sabido es que adquirió los terrenos necesarios y mandó construir una calzada, el actual Paseo de la Reforma, desde la plaza de la estatua de Carlos IV hasta el pie del castillo de Chapultepec y una rampa que llegara a la explanada por el lado occidental. ${ }^{3}$

En el archivo de la Dirección General de Geografía y Meteorología del edificio del Observatorio Astronómico Nacional en Tacubaya, se hallan varios planos, en su mayoría, dibujados por el arquitecto austriaco C. Kaiser, que se refieren a proyectos de remodelación del alcázar de Chapultepec, ${ }^{4}$ En estos proyectos podemos observar las variaciones experimentadas con respecto a los planos coloniales de 1787 que se localizan en el Archivo de Indias de Sevilla, 5 relacionados al edificio

1 Justino Fernández, "El siglo romántico - El arte de México en el siglo XIX", Cuarenta siglos de plásicica mexicana - Arte moderno y contemporáneo. Editorial Herrero, S. A. México, 1971, p. 36.

2 Michael Drews, "Proyectos en el Imperio", Palacio Nacional, México Secretaría de Obras Públicas. Bajo el patrocinio de la Secretaría de Hacienda y Crédito Público. México, 1976, pp 201-208 y nota 45 en p. 319.

3 Jesús Romero Flores, Chapultepec en la historia do México. Biblioteca enciclopédica popular. Segunda época, nứm. 175. Secretaria de Educación Pública. México, 1947, p. 69 .

4 Colección "Orozco y Berra", de la mapoteca del Observatorio Citaremos los planos por su número de control.

5 Diego Angulo Iñiguez, Planos de monumentos arquitectónicos de América y Filipinas existentes en el Archivo de Indias. Láminas I. Universidad de Sevilla. 
realizado por el ingeniero Manuel Agustín Mascaró (n. en Barcelona, 1748; m. en Orizaba, 1812 (?) ), quien desde el 5 de diciembre de 1785 hasta el 24 de octubre de 1787 estuvo al frente de las obras ${ }^{6}$ de la "Real casa y castillo de Chapultepec". 7

El palacio de Chapultepec, que albergara de 1842 a 1863 el Colegio Militar, ${ }^{8}$ poseía varias obras de fortificación para hacer frente a las tropas norteamericanas en $1847,{ }^{9}$ pero a pesar de todo, el edificio sufrió serios estragos causados por los bombardeos del invasor, mantenidos durante catorce horas durante los días 12 y 13 de septiembre del mismo año, ${ }^{10}$ a tal grado que el general Miguel Miramón, quien en 1858 ocupaba la presidencia de la República, mandó trasladar a los alumnos del Colegio Militar al antiguo edificio del Colegio de San Pedro y San Pablo, en vista de lo ruinoso en que se hallaba el alcázar. ${ }^{11}$

Remodelación del palacio virreinal: El archiduque Fernando Maximiliano de Habsburgo, hermano de Francisco José, emperador de Austria, y su esposa, la archiduquesa Carlota Amalia, hija del rey de Bélgica, Leopoldo. II, llegaron a la ciudad de México el 12 de junio de 1864. Al igual que los presidentes que habían precedido al imperio, Maximiliano escogió como residencia oficial el palacio de Chapultepec, que fue remozado para adecuarse a los gustos y necesidades de los emperadores. 12

Se tapizaron y se pintaron de nuevo todas las habitaciones, se hicieron traer nuevos muebles de Europa, y se destinó para comedor la

${ }^{6}$ Jorge Flores $\mathrm{D}$., Historia del olvidado ingeniero, constructor del castillo, Manuel Agustin Mascaró, constructor de Chapultepec, citado en Jesús Romero Flores, op. cit, pp. 40-41.

7 Francisco de Paula de Arrangoiz, México desde 1808 hasta 1867. Prólogo de Martín Quiriarte. Segunda Edición. "Sepan Cuántos..." núm. 82. Editorial Porrúa, S. A. México, 1968, pp. 249-250

8 Manuel Orozco y Berra, Apéndice del Diccionanio universal de historia y geografia - Colección de articulos velativos a la República Mexicana. Imprenta de J. M. Andrade y F Escalante México, 1856, pp. 32-33. También en Manuel Rivera Cambas, México pintoresco, artistico y monumental. Tomo primero. Imprenta de la Reforma. México, 1880, p. 322.

- Idem, pp. 37-38.

10 Relatos detallados de estos sucesos se hallan en Manuel Orozco y Berra, op "cit., p. 39, y en Antonio García Cubas, El libro de mis recuerdos. Colección "México en el siglo XIX". Editorial Patria, S. A. México, 1950, p. 569.

11 Jesús Romero Flores, op. cit., p. 68 .

12 José Luis Blasio, Maximitiano intimo, citado en Alfonso Teja Zabre, Chapultepec. Guia histórica y descriptiva, con un plano pictórico del bosque. Publicaciones de la Secretaría de Hacienda y Crédito Público. México, 1938, pp. 126-127. 
gran sala del piso principal, quedando a la derecha del comedor la recámara del emperador y a la izquierda la de la emperatriz. Se construyó también un corredor cubierto, que servía para que el emperador, paseándose mientras se le leía la correspondencia, contemplara el maravilloso paisaje. Igualmente hizo que se cubrieran los jardines con plantas exquisitas y con magníficas estatuas y con espléndidos jarrones de mármol blanco y finísimo.

Un plano de la parte superior del castillo de Chapultepec, ${ }^{13}$ titulado Plan de la partie supérieure du château de Chapultepec, firmado por E. Suban y sin fecha, muestra una disposición diferente que la anteriormente citada. Probablemente se trata de un anteproyecto, de la planta alta de lo que corresponde al palacio virreinal construido en 1787. Las escaleras coinciden con aquéllas indicadas en dicho plano, y asimismo, los muros principales, pero hay ligeros cambios en otros elementos, como puede verse al compararse el plano publicado por Diego Angulo Íñiguez con aquél hallado en el Observatorio. Damos a continuación la traducción de los letreros, de acuerdo con la numeración de los locales:

1. Antesala

2. Sala de espera y sala de los ministros

3. Antesala

4. Privado del secretario

5. Privado y biblioteca del emperador

6. Oficiales del servicio

7. Retrete y baño, tocador

8. Recámara del emperador

9. Pasillo

10. Servicio

11. Retrete, baño y tocador

12. Comunicación

13. Pasillo

14. Recámara de la emperatriz

15. Sirvientes

16. Antesala

17. Ujicres

18. Sala de damas

19. Antesala

20. Salón

13 Plano núm. 1535 del legajo mencionado en nota 4. 
21. Comedor

22. Sala de fumar

23. Oficio

24. Galexía

25. Bodega de servicio

26. Farmacia

Locales sin número: Apartamentos, cocina, jardín, capilla.

Existe un proyecto definitivo del arreglo de la planta baja del palacio virreinal para las necesidades del emperador Maximiliano, ${ }^{14}$ que nos sirve de comparación con el plano anterior "Es un dibujo en tinta china, en el cual parece que se indicó la posición del pórtico agregado equivocadamente, por lo que se le pegaron dibujos a tinta china y en papel de lino transparente encima, que muestran la situación correcta. Las indicaciones "Bodega de vinos", "Cuerpo de guardia de los húsares" y "Gabinete de S. M.", develan su época.

Como detalle del plano anterior nos sirven dos proyectos de remodelación del cubo de escaleras del palacio virreinal, que con respecto al proyecto antiguo sobresale atrás del edificio, con lo que se obtiene un vestíbulo más amplio. ${ }^{15} \mathrm{~A}$ esto corresponde el corte por el palacio virreinal por el cubo de escalera remozado, con su pórtico agregado. Es un dibujo a lápiz, pasado pancialmente a tinta china ${ }^{16}$ y que sustituye aquel titulado Perfil que pasa por la línea 5, 6, 7 del plano colonial. Al compararlo con éste, se nota cómo el edificio se aumenta hacia la explanada en el pórtico agregado y hacia la espalda en el cubo de escaleras.

El plano siguiente, ${ }^{1 \tau}$ es un detalle del anterior, a tinta china, lápiz y acuarela, inconcluso y muestra una pared del cubo de escaleras en la planta baja del palacio virteinal. $\mathrm{El}$ interior neoclásico es muy severo, salvo el tratamiento algo libre de las volutas de los capiteles jónicos de las columnas adosadas a la pared. En el dintel de la puerta a la izquierda se advierte el monograma de Maximiliano: dos letras $M$, entrelazadas por una I. A la derecha se nota, dibujado a lápiz, un busto de Maximiliano sobre un pedestal.

14 Legajo núm 1564, titulado Proyectos diversos de detalles del palacio de Chapultepec comprendiendo las hojas núms. 28, 29, 30, . , 119. En este caso, es el plano núm. 70 de este legajo.

15 Plano núm. 69 del legajo núm. 1564.

16 Plano núm. 90 del legajo núm. 1564.

$1 \tau$ Plano núm. 89 del legajo núm. 1564. 
Un alzado del pórtico adicionado al palacio virreinal, ${ }^{18}$ hecho en tiempos del emperador Maximiliano, confirma con la anotación a lápiz: "Eje del balcón del comedor" lo observado por José Luis Blasio en el sentido de que la parte central del edificio de hecho se destinara para comedor, y que a uno y otro lado de él se localizaran las habitaciones del emperador y de la emperatriz.

El siguiente plano, un magnífico dibujo a lápiz, ${ }^{10}$ firmado por $\mathrm{C} . \mathrm{K}$. (Kaiser), muestra un proyecto para el cuerpo central de la fachada principal del palacio virreinal. Desde luego, con su reloj y campanario, sus balaustradas, águilas y serpientes de bronce desvirtúan por completo la fisonomía estrictamente neoclásica del edificio. Demos gracias a Dios que este proyecto aparatoso no haya sido realizado, al igual que los diseños para la restauración del Palacio Nacional, también elaborados por $\mathrm{C}$ Kaiser, que se contienen en el legajo número 1565: cuatro planos, del 1 de enero de 1866. Eso sí, magníficos dibujos a tinta china, pero ide la que nos hemos salvado! ${ }^{20}$ En el ángulo superior derecho se sacó en detalle una perspectiva del reloj.

Un plano a tinta china, Corte del vestibulo de Chapultepec, ${ }^{21}$ relativo al palacio virreinal, ostenta dentro del pórtico agregado una portada neoclásica con frontón triangular y una estatua de Euterpe sobre un pedestal.

Proyectos de los arquitectos austriacos: $\mathbf{E l}$ arquitecto austriaco $\mathrm{C}$. Kaiser, un hábil dibujante, a notarse por sus planos, acompañó probablemente al archiduque desde Austria para prestarle sus servicios en México. De él se conservan los magníficamente dibujados pero desatinados proyectos para la remodelación del Palacio Nacional, y ya comentamos algunos relativos al remozamiento del edificio que tengo por palacio virreinal, del castillo de Chapultepec. Ahora nos toca analizar algunas ideas suyas respecto a los accesorios del propio alcázar como del parque.

Un proyecto indudablemente inspirado en la Gloriette del palacio de Schönbrunn de Viena muestra un plano firmado por C. Kaiser y fechado el 23 de febrero de $1866 .{ }^{22}$

Este alarife austriaco no sólo proyectó una capilla para el Palacio

18 Plano núm 64 del legajo núm 1564

19 Plano núm 61 del legajo núm $156 t^{\prime}$

20 Estos planos han sido publicados en la memoria sobre el Palacio Nacional de la nota 2.

21 Plano núm. 103 del legajo núm. 1564.

22 Plano núm. 33 del legajo núm. 1564. 
Nacional, sino también una para el alcázar de Chapultepec, como se ve en una hoja con un dibujo a lápiz, con título en alemán KapelleChaplt., "Capilla-Chapultepec", firmado por C. Kaiser, ${ }^{23}$ El apunte muestra la capilla, adosada al caballero alto de alcázar, concebida en un estilo neorrománico, con una torre de transepto parecida al mausoleo de Halicarnaso, sólo de proporciones esbeltas.

El arquitecto proyectó también unas casas habitación unifamiliares, probablemente destinadas a personajes más o menos conspícuos de la corte de Maximiliano. De estas viviendas existen planos preliminares y las que comentamos, ${ }^{24}$ mas no llegaron a realizarse los edificios. Los letreros que aluden a las dependencias, en alemán, dan pie a esta idea. Aquí damos sus equivalencias en español:

$\begin{array}{ll}\text { Ankleide und Bad } & =\text { Vestidor y baño } \\ \text { Schlafzimmer } & =\text { Recámara } \\ \text { Salon } & =\text { Salón } \\ \text { Empfangsaal } & =\text { Sala de recepción } \\ \text { Fremdenzimmer } & =\text { Cuarto de huéspedes } \\ \text { Garderobe } & =\text { Guardarropa } \\ \text { Vorzimmer } & =\text { Vestíbulo } \\ \text { Hausflur } & =\text { Pasillo } \\ \text { Speise-Salon } & =\text { Comedor } \\ \text { Küche } & =\text { cocina }\end{array}$

:Proyectos con textos en alemán pero escala gráfica en varas castellanas! Existen incluso cortes ${ }^{25}$ a través de estas casas y un proyecto de fachada de la vivienda del jardinero, según se deduce del letrero encima de la puerta, en el dibujo respectivo. Todos estos planos, a tinta china y en papel grueso, muestran el estilo de C. Kaiser, y los cortes están filmados por él. Un diseño para un hogar de chimenea, coronado con frontón triangular neoclásico y rematado con candelabros, pone de relieve también el estilo de dibujo del arquitecto C. Kaiser, $\tan$ característico por sus asciurados tupidos a tinta china.

De todo esto se entresaca que el arquitecto $\mathrm{C}$ Kaiser trasladó sus recuerdos europeos al Continente Americano, al plasmarlos en sus proyectos que son de una filiación marcadamente vienesa del siglo xix, como se

\footnotetext{
23 Plano núm. 37 del legajo núm. 1564 .

24 Planos 35 y 36 del legajo citado.

25 Como el plano núm 88 del mismo legajo.
} 

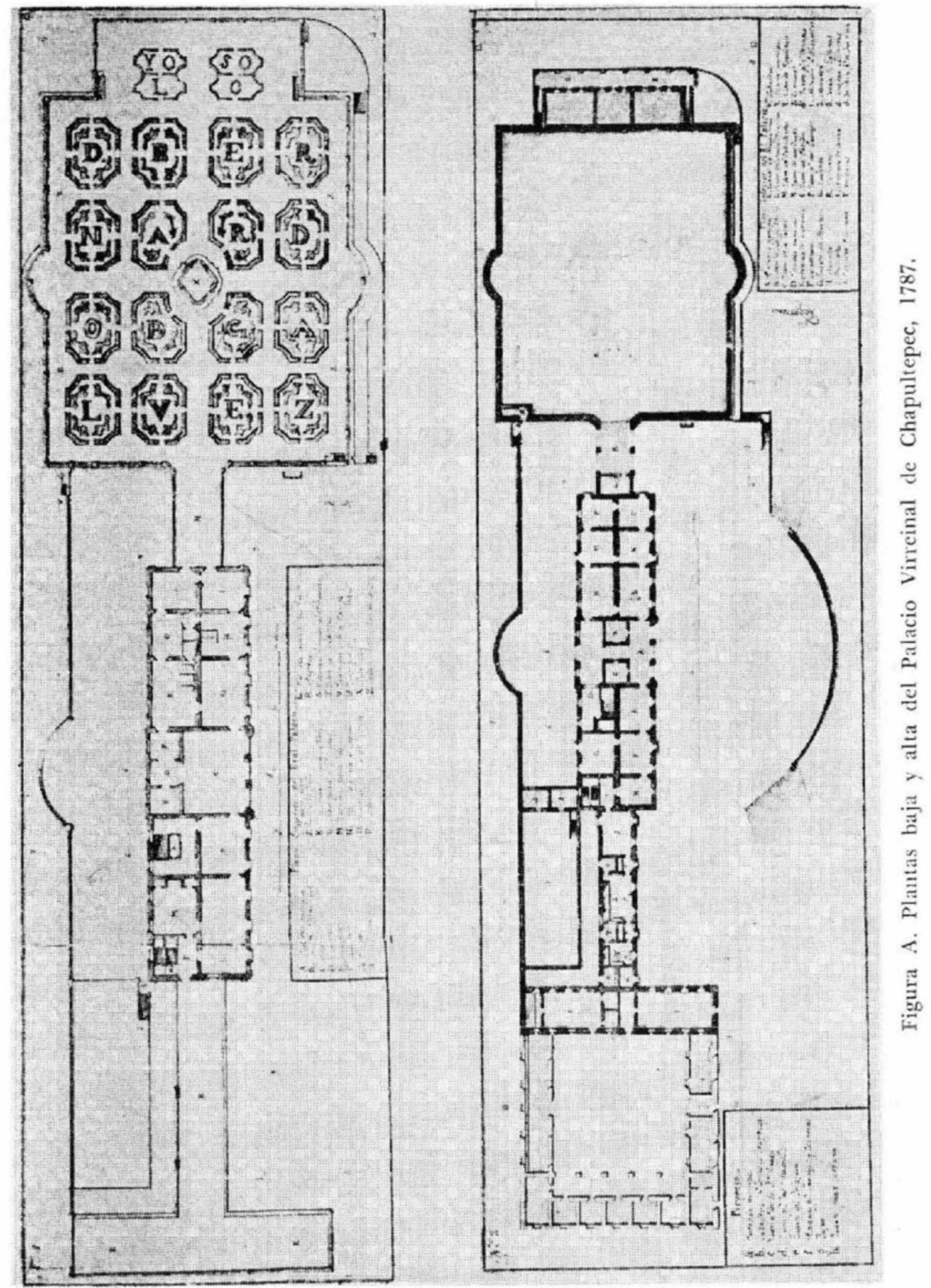

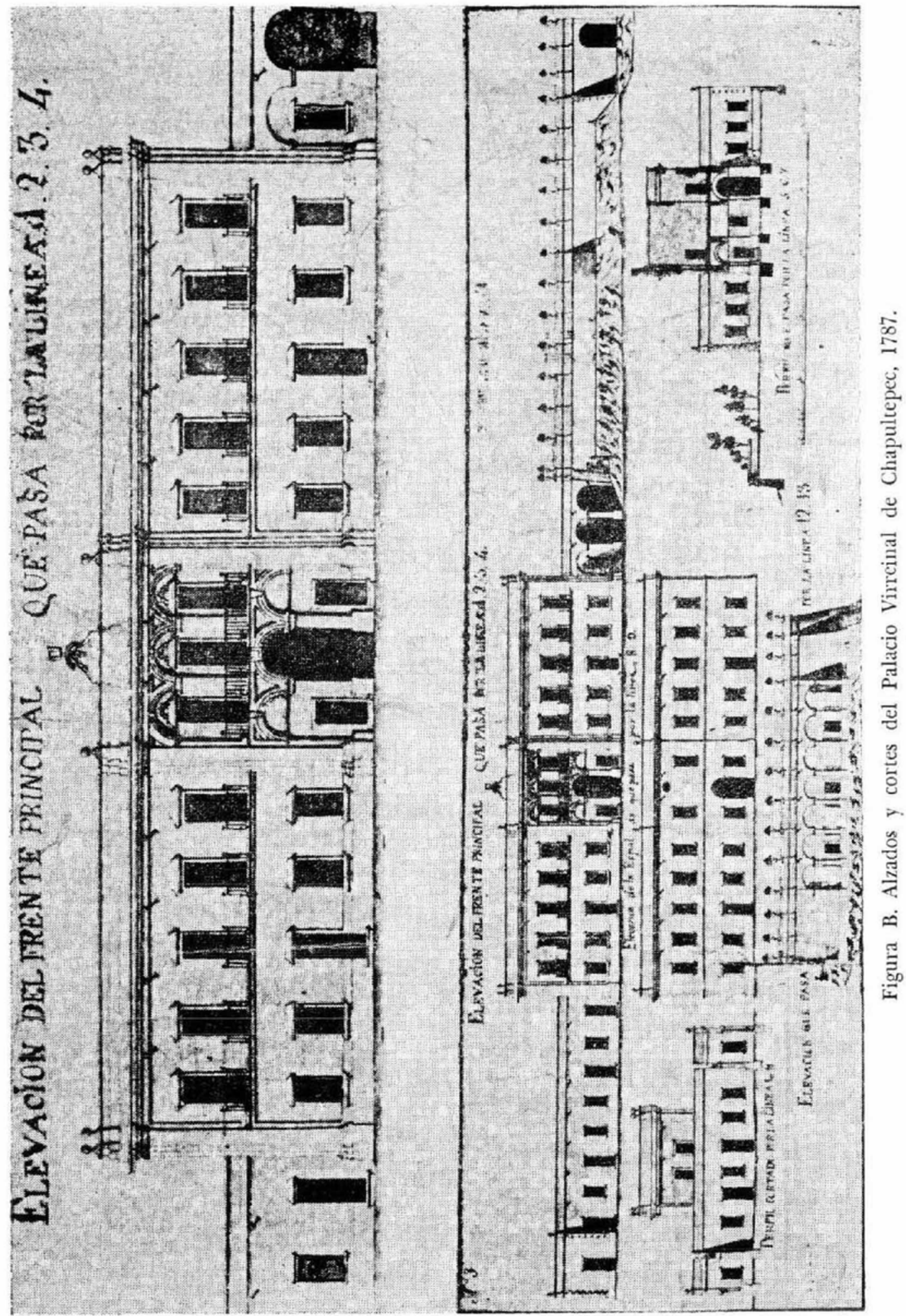


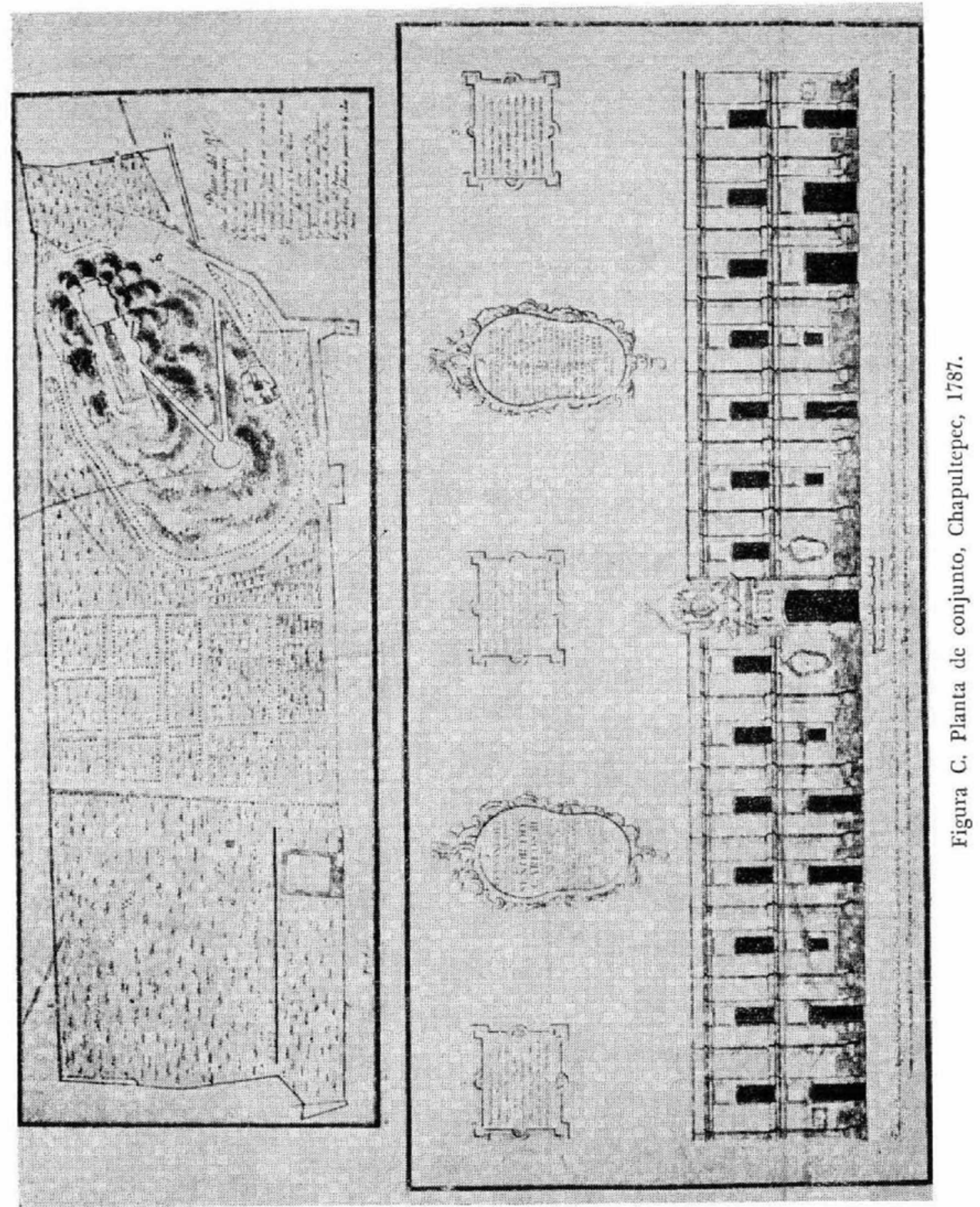




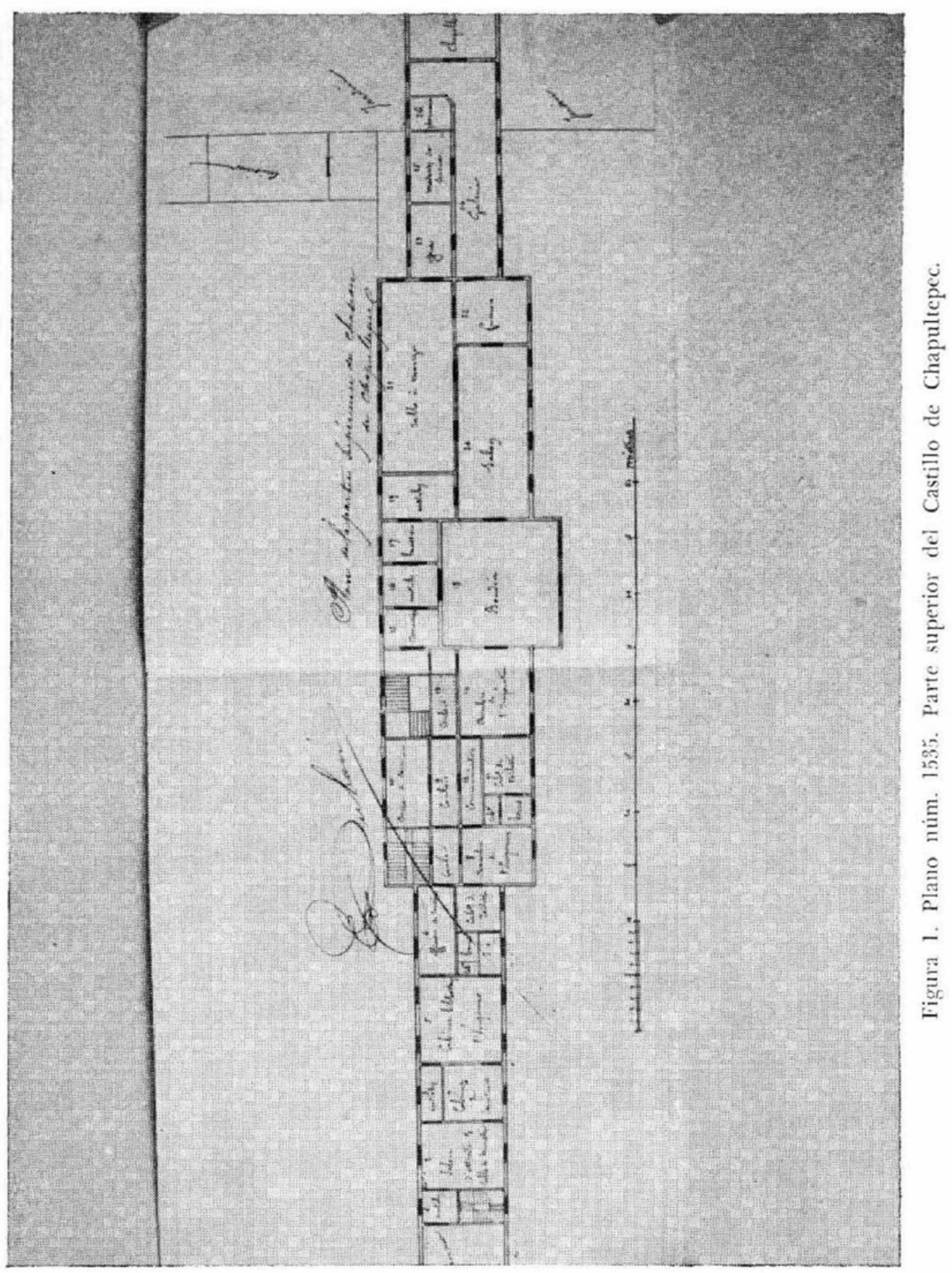




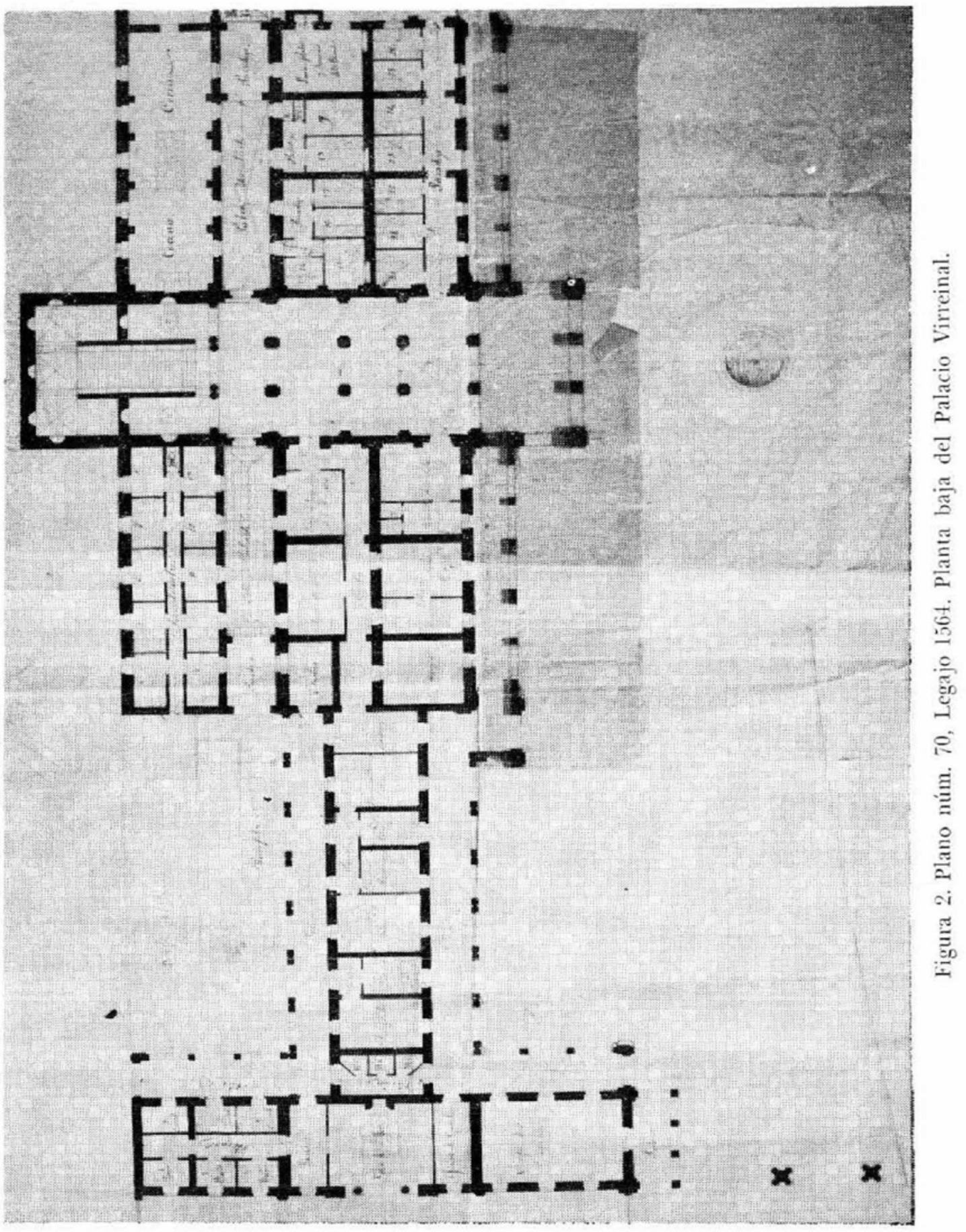




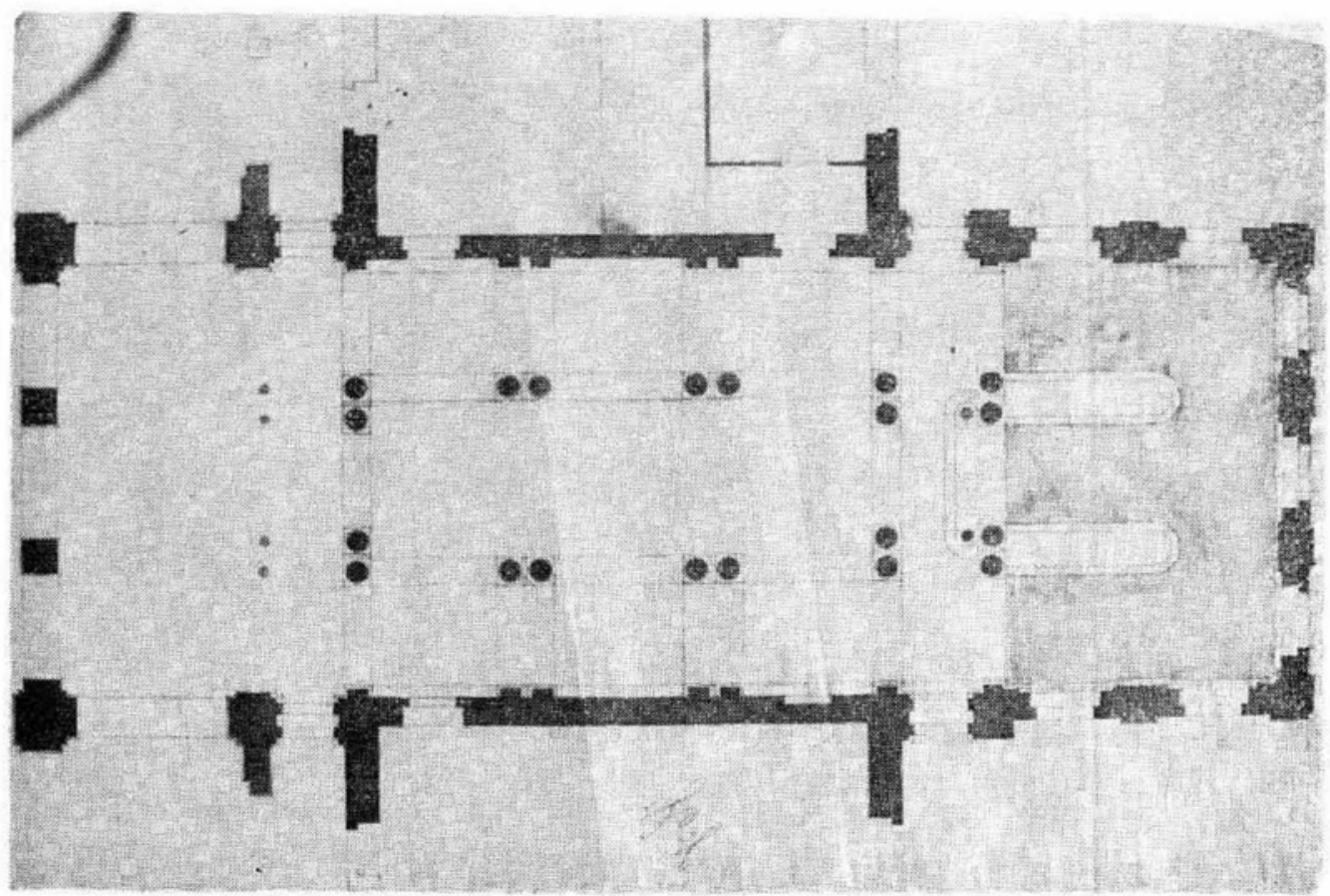

Figura 3. Plano núm. 69, Legajo 1564. Fscalera, planta baja.

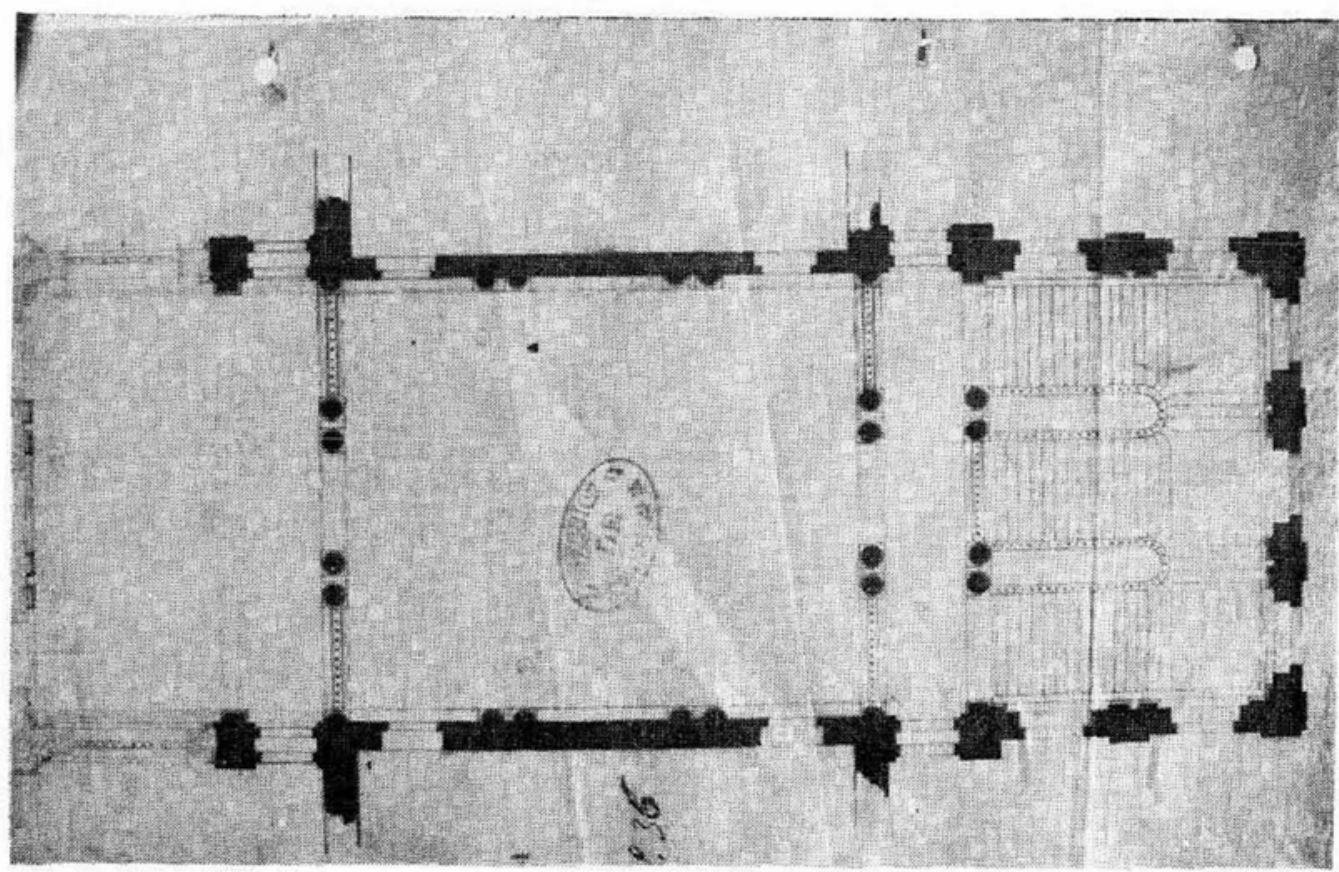

Figura 4. Plano núm. 69, Legajo 1564. Escalera, planta alta. 
DOI: http://dx.doi.org/10.22201/iie.18703062e.1983.51.1169

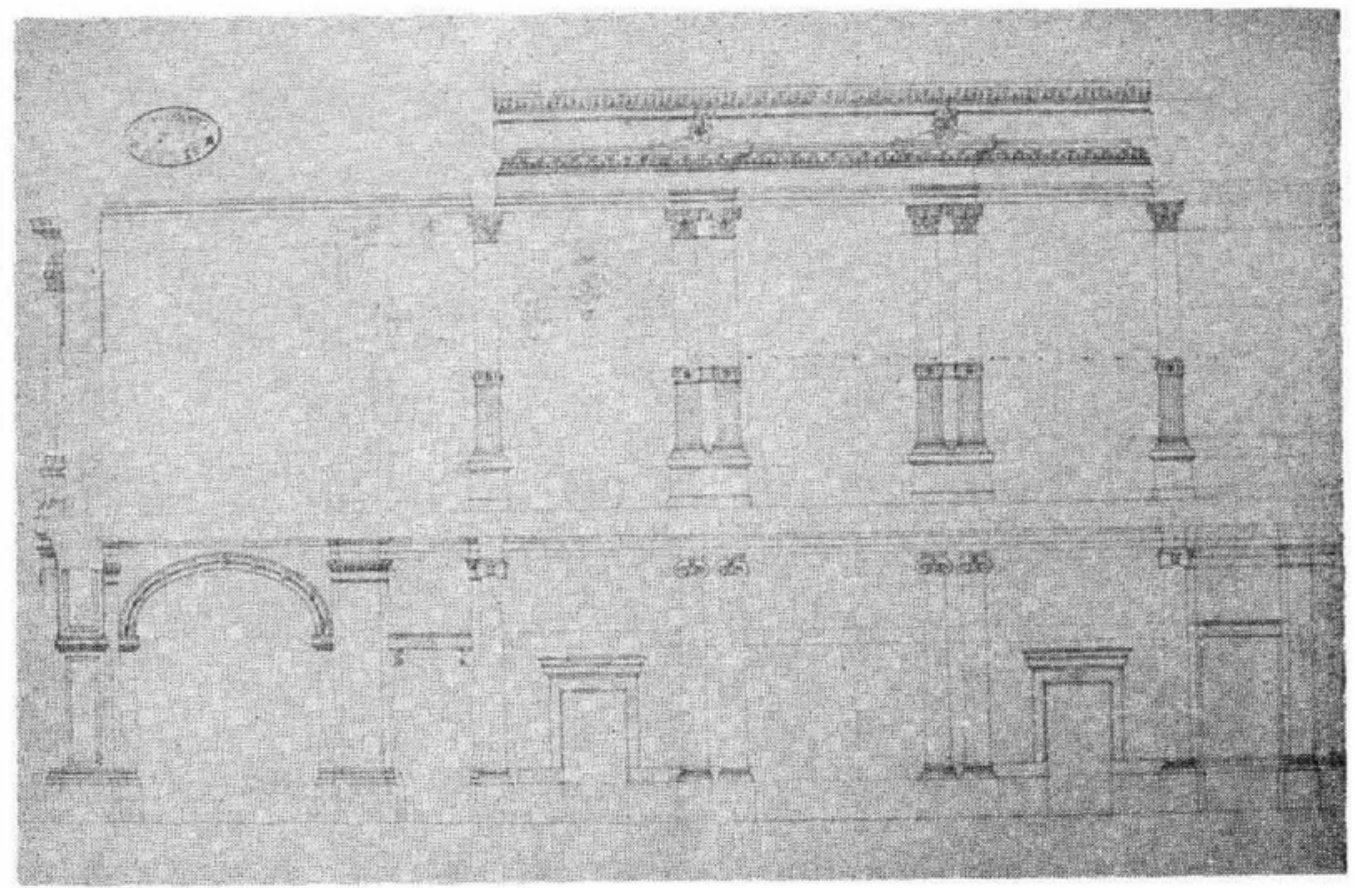

Figura 5. Plano núm. 90, Legajo 1564. Corte por el cubo de las escaleras del Palacio Virreinal.

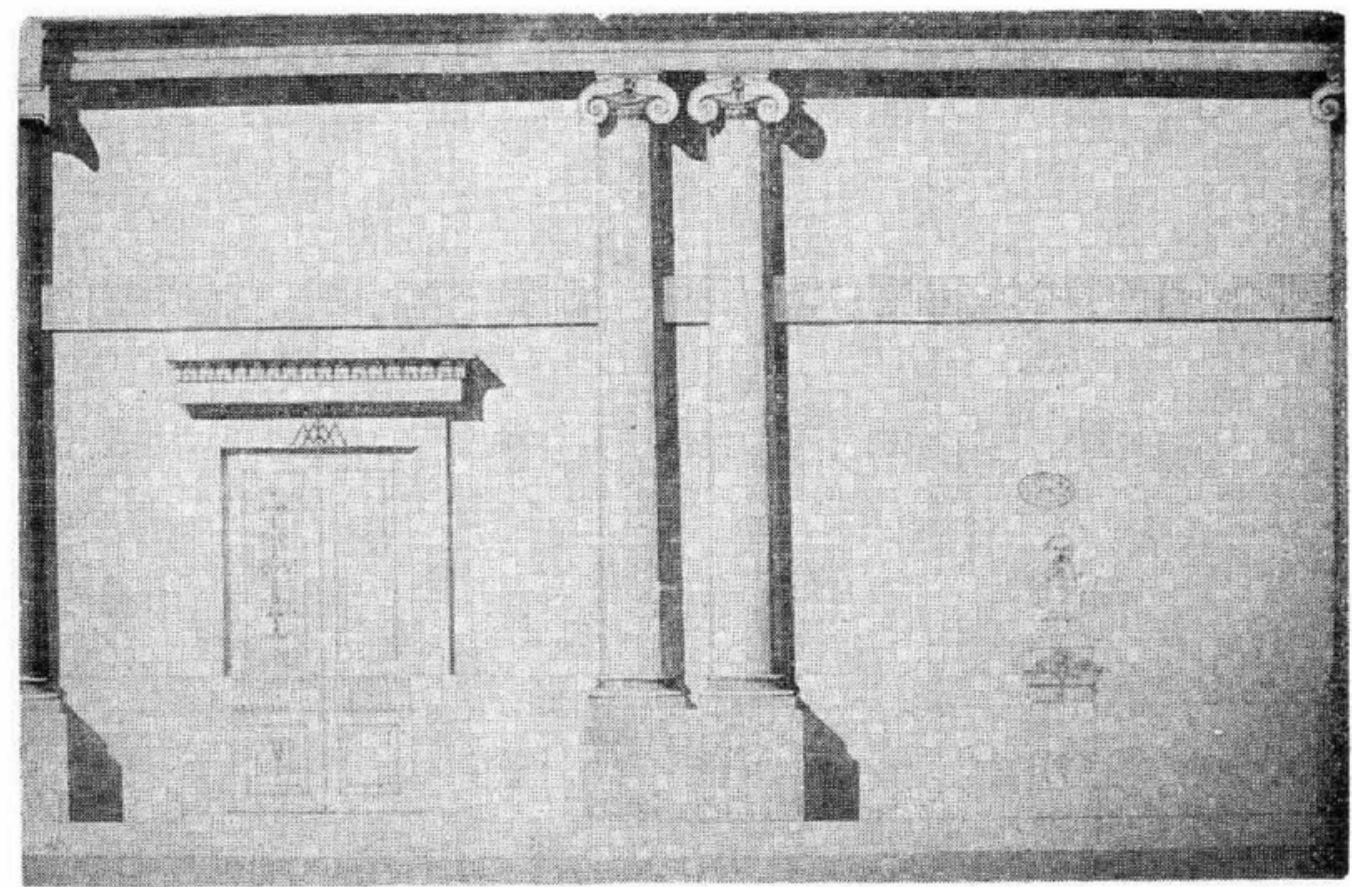

Figura 6. Plano núm. 89, Lcgajo 1564. Pared del cubo de las escaleras, planta baja. 
DOI: http://dx.doi.org/10.22201/iie.18703062e.1983.51.1169

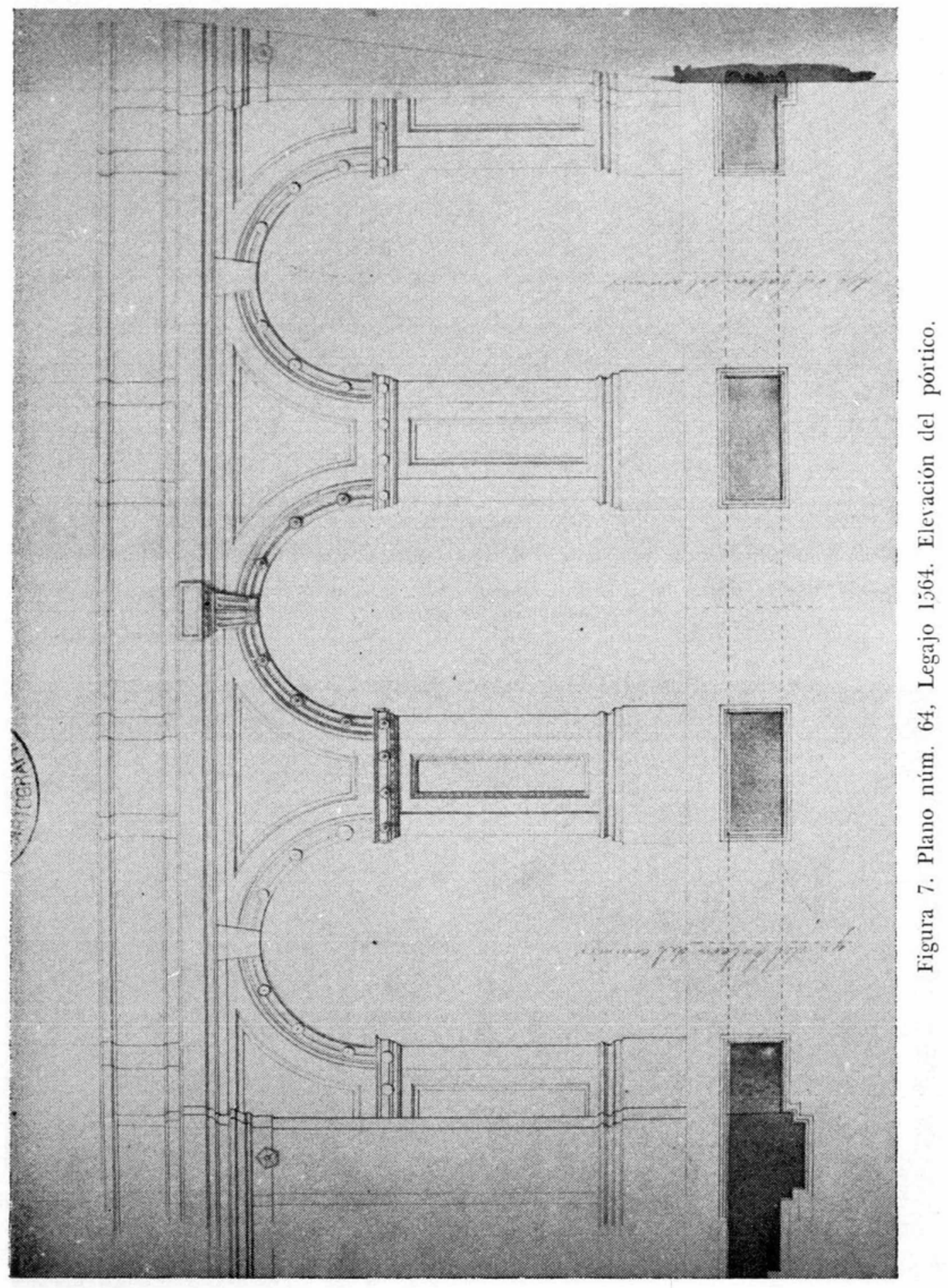




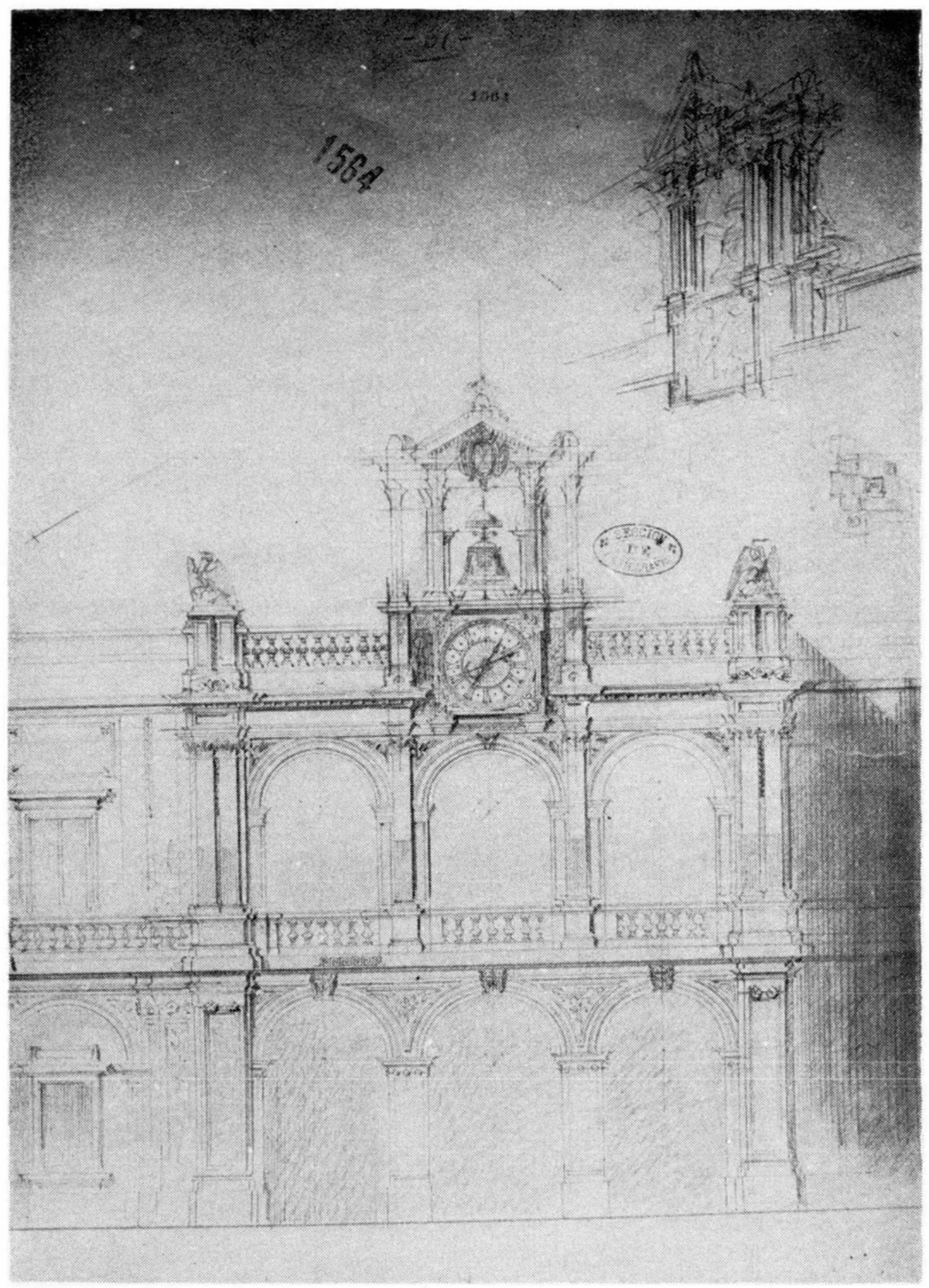

Figura 8. Plano núm. 61, Legajo 1564. Fachada del Palacio Virreinal, 
DOI: http://dx.doi.org/10.22201/iie.18703062e.1983.51.1169

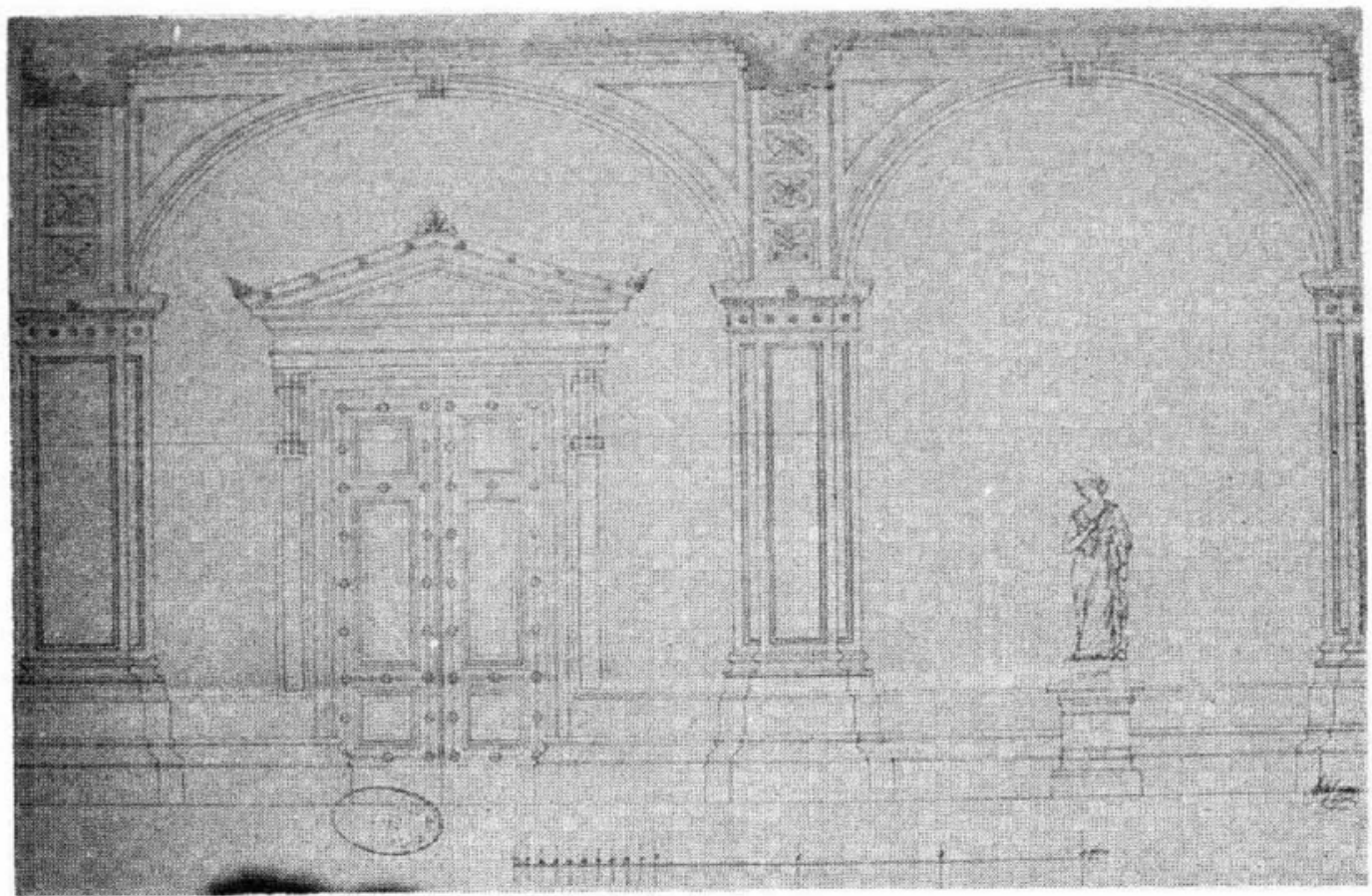

Figura 9. Plano núm. 103, Legajo 1564. Corte del vestíbulo del Castillo de Chapultepec.

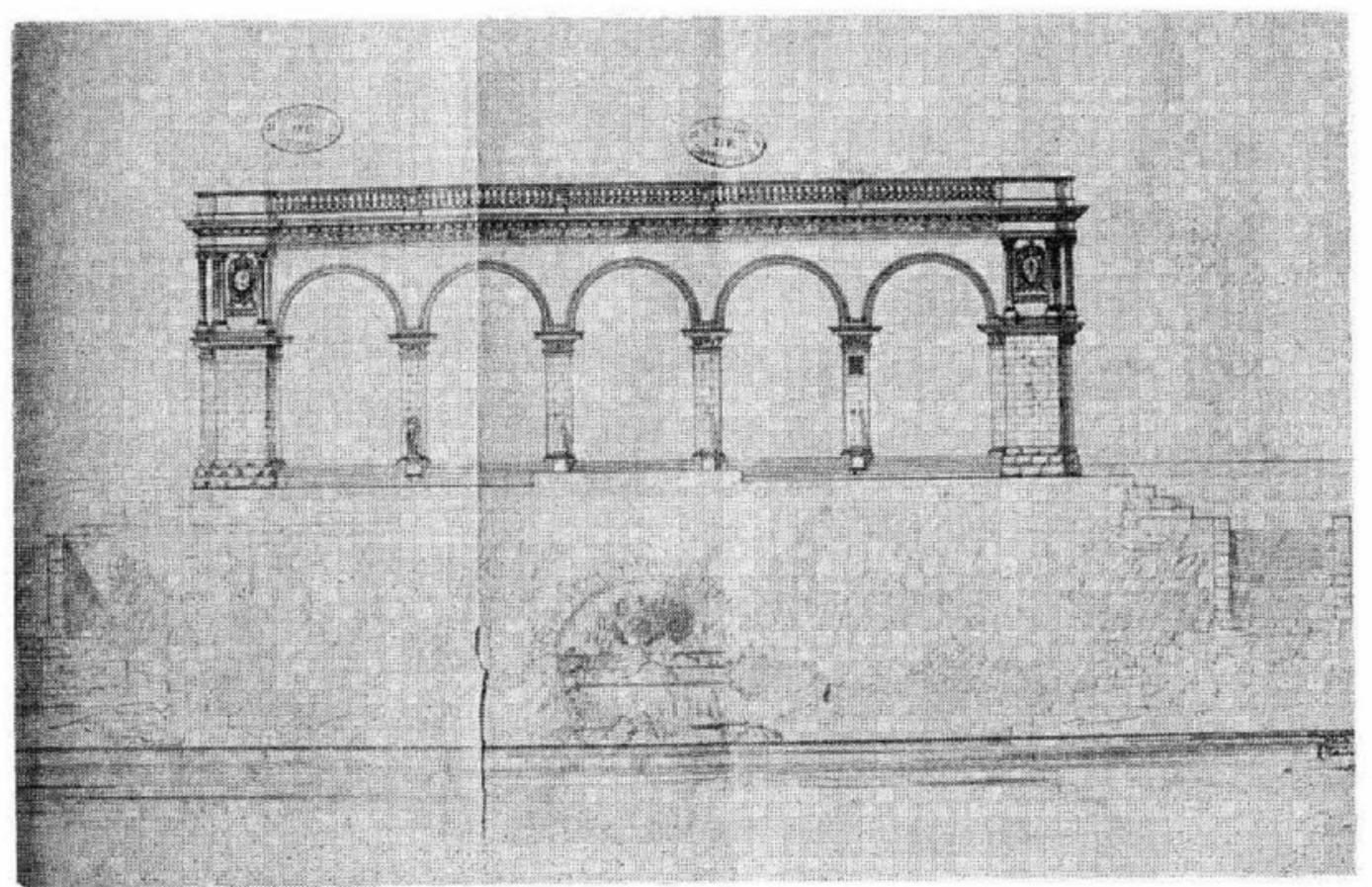

Figura 10. Plano núm. 33, Legajo 1564. Fachada de la fuente. 
DOI: http://dx.doi.org/10.22201/iie.18703062e.1983.51.1169

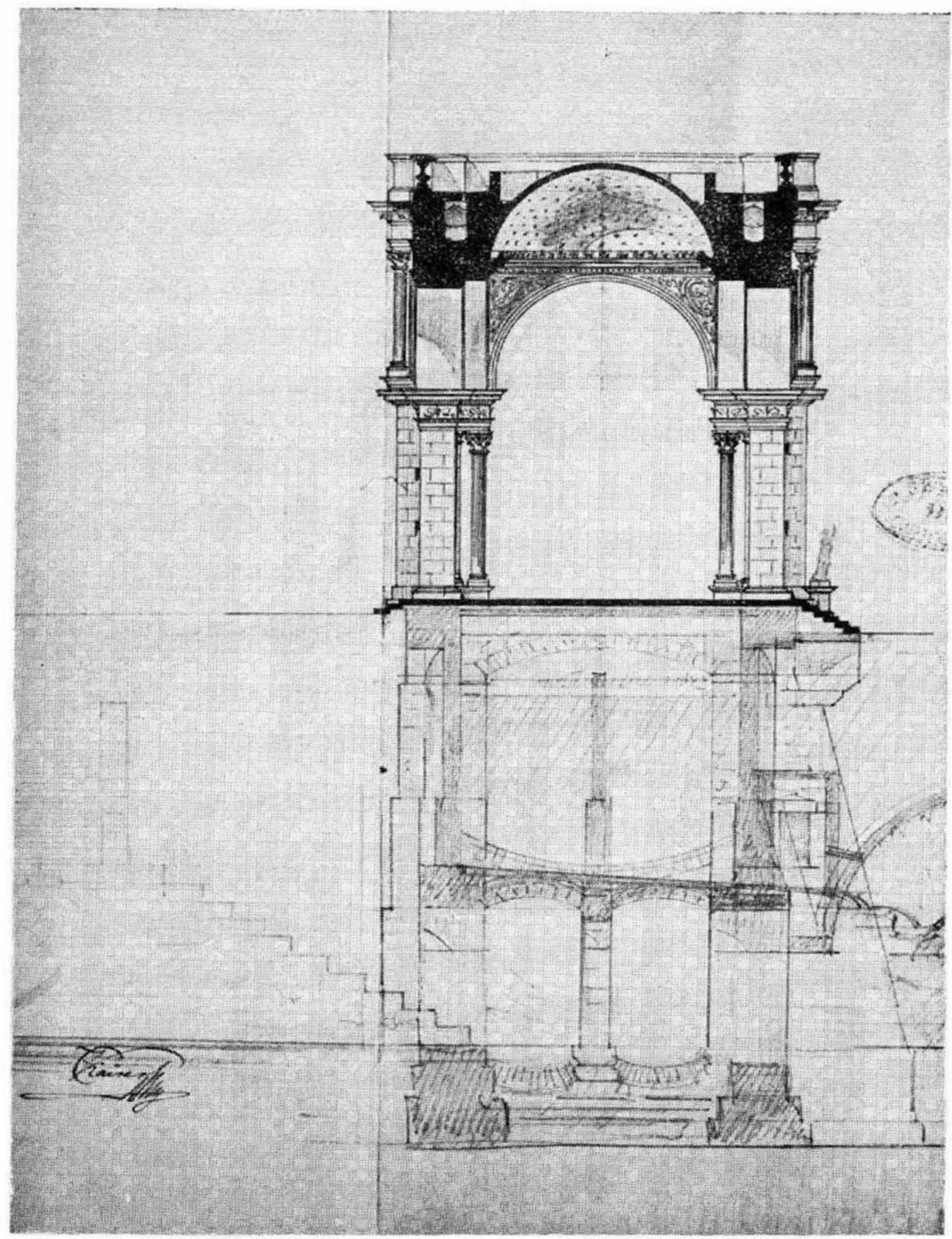

Figura 11. Plano núm. 33, Legajo 1564. Corte de la fuente. 


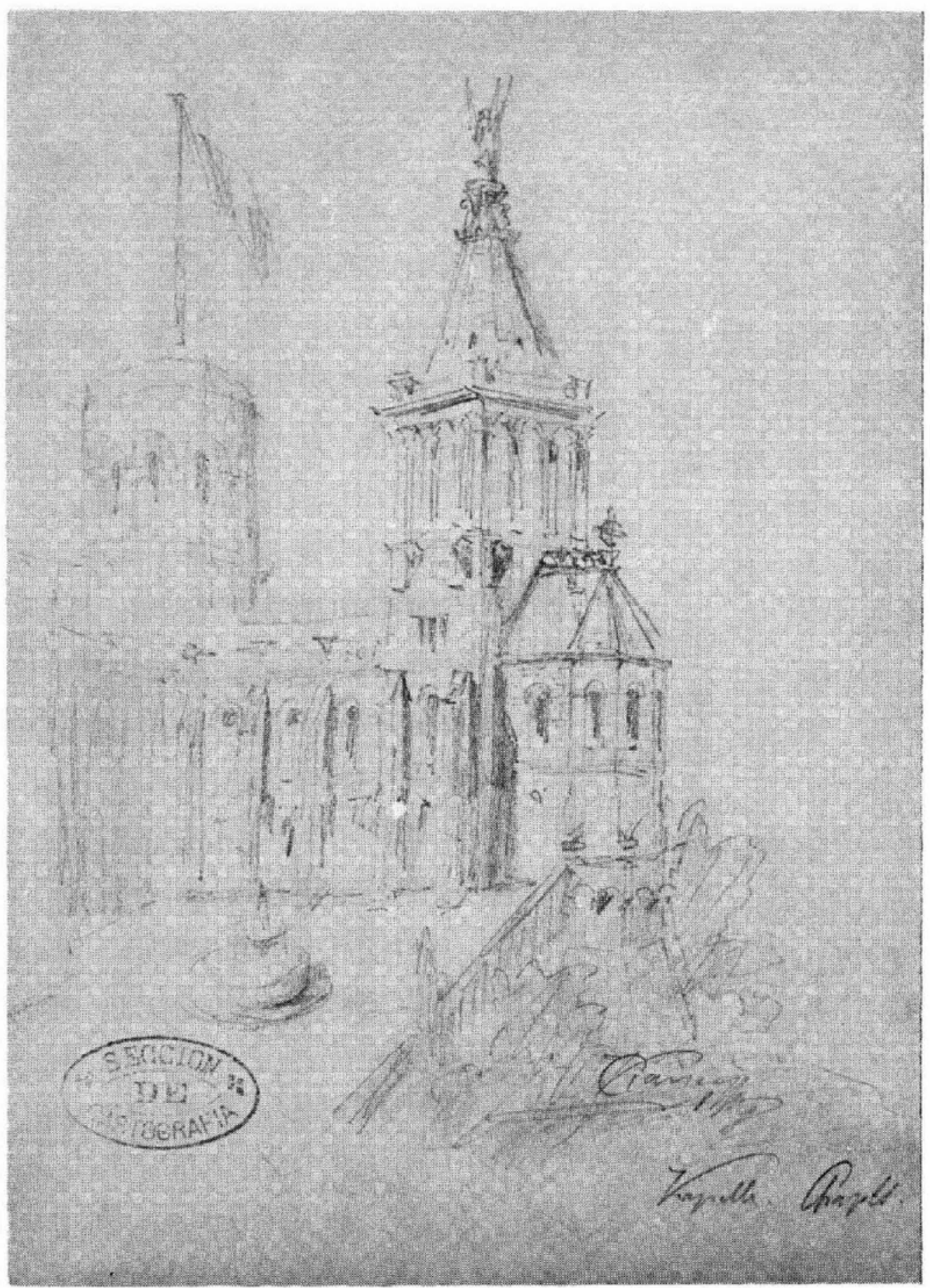

Figura 12. Plano núm. 37, Legajo 1564. Vista de la capilla. 
DOI: http://dx.doi.org/10.22201/iie.18703062e.1983.51.1169

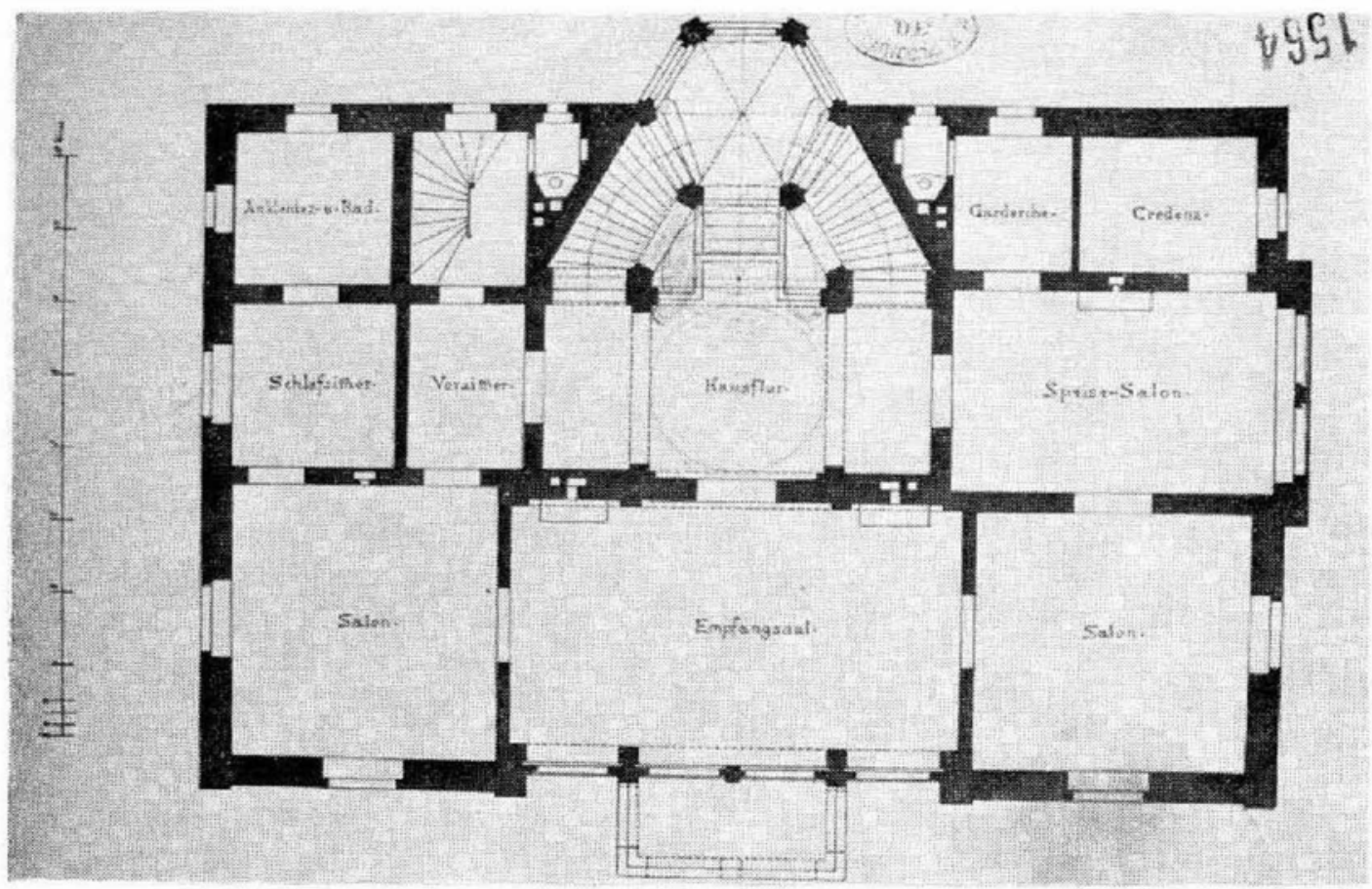

Figura 13. Plano núm. 35, Legajo 1564. Casa particular, planta.

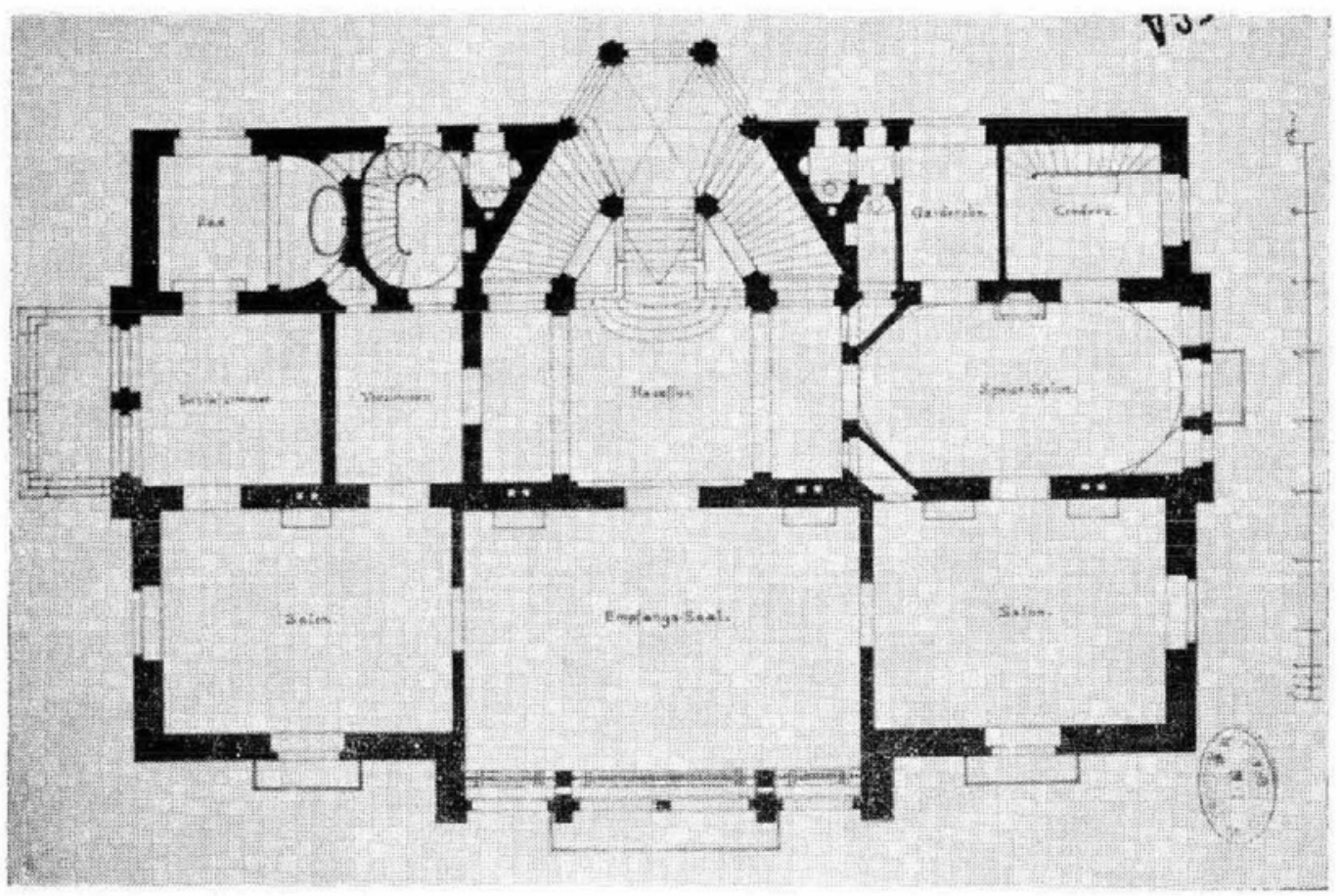

Figura 14. Plano núm. 36, Legajo 1564. Casa particular, planta alternativa. 


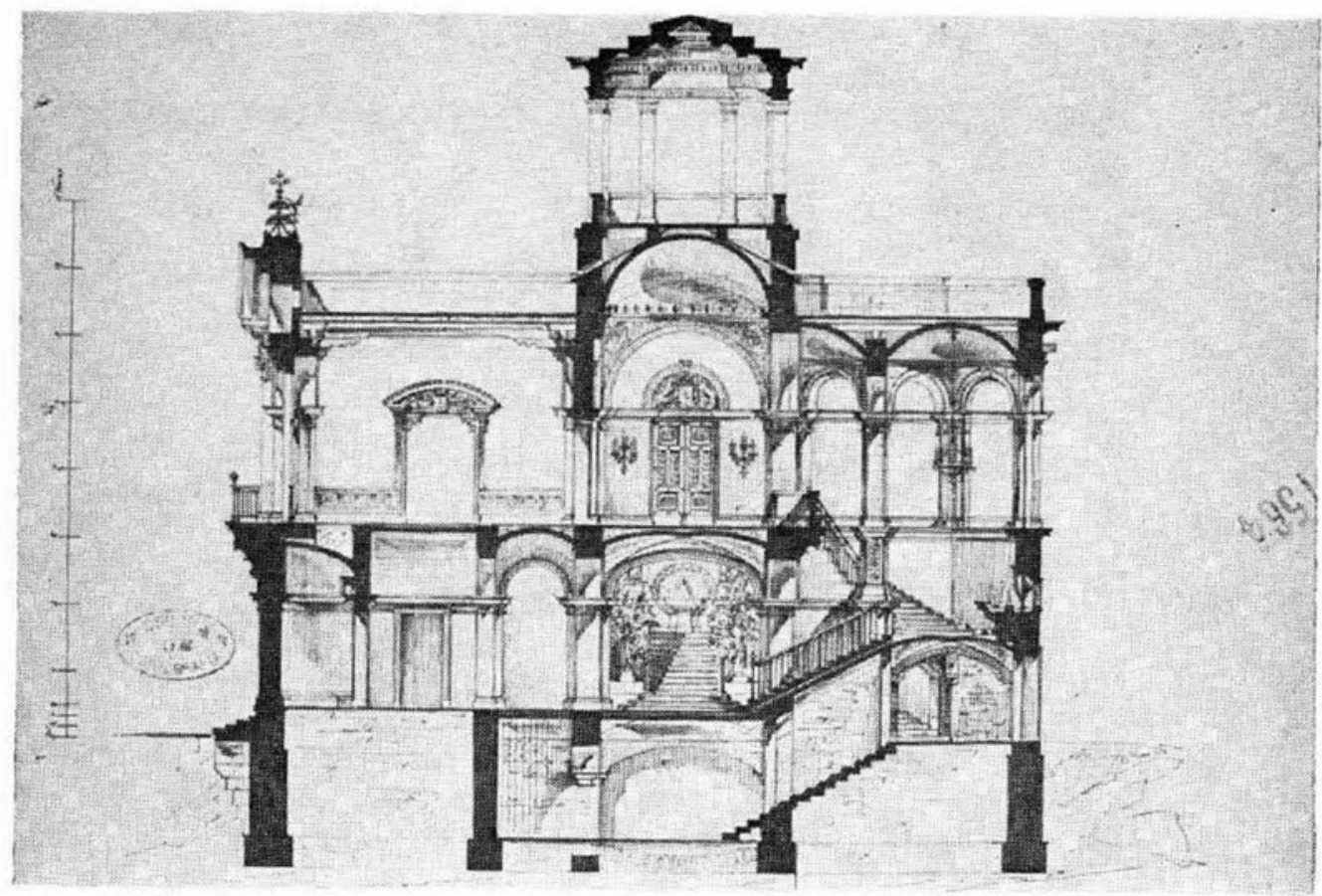

Figura 15. Plano núm. 38, Casa particular, corte.

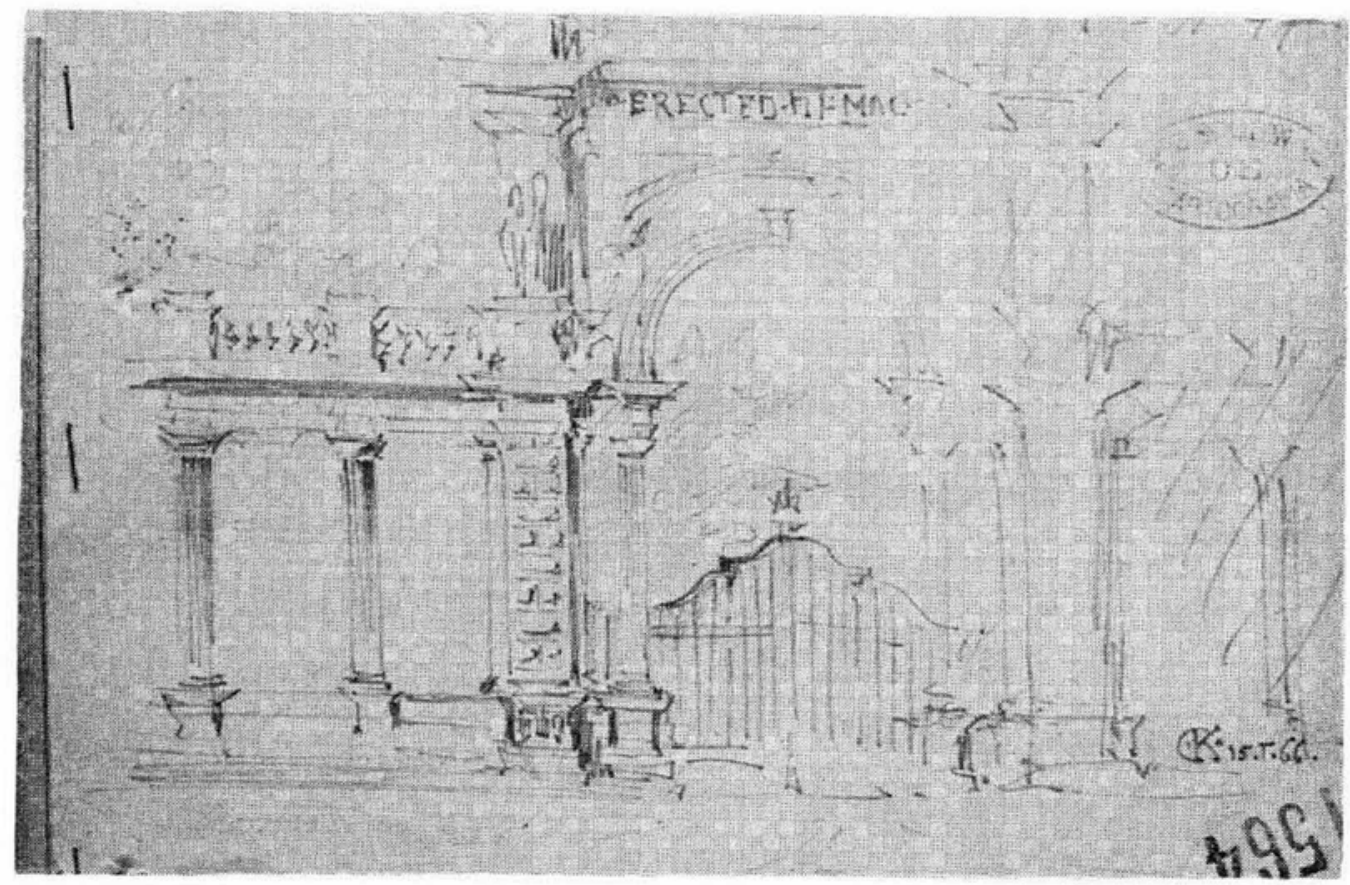

Figura 16. Plano núm. 47, Legajo 1564. Puerta principal de la rotonda. 
DOI: http://dx.doi.org/10.22201/iie.18703062e.1983.51.1169

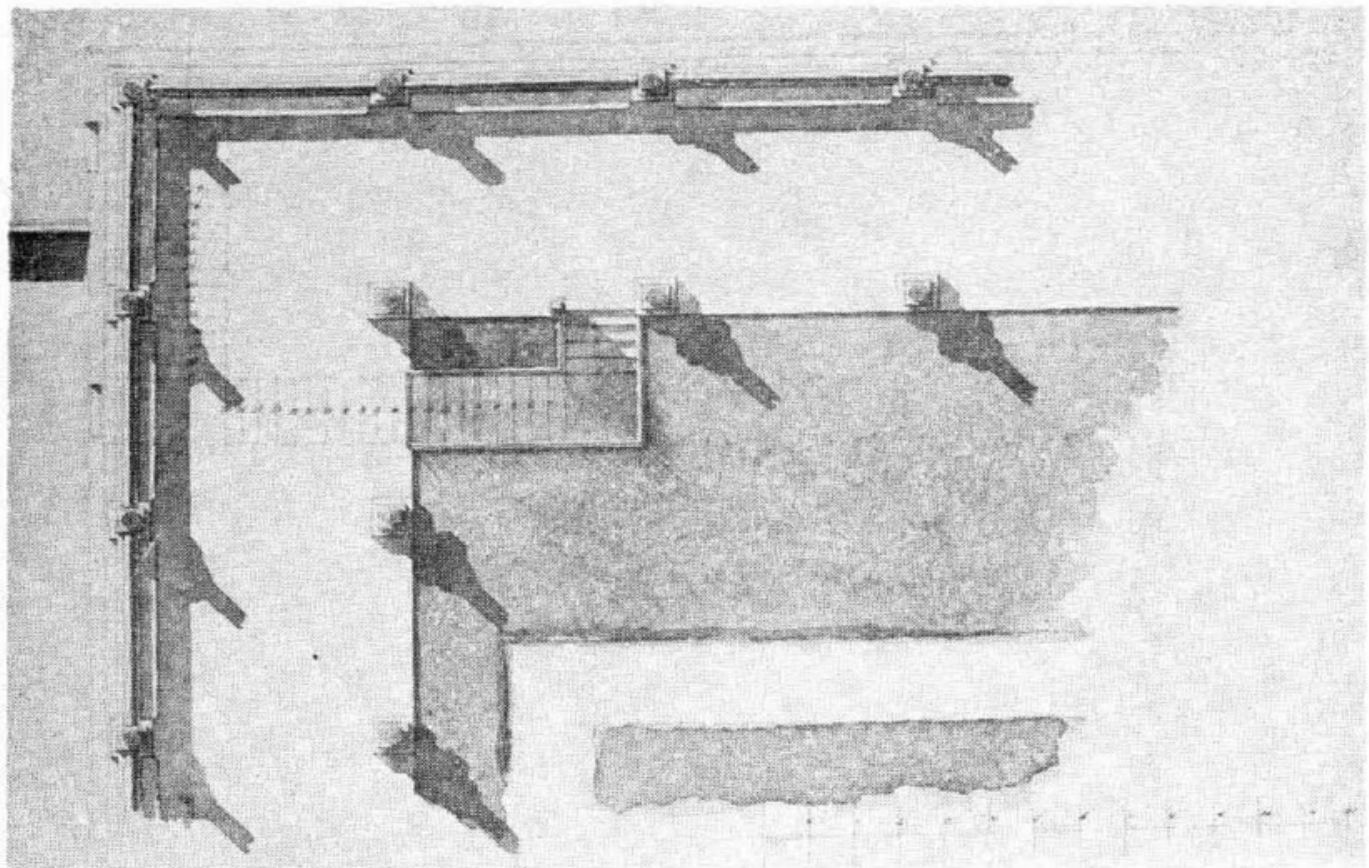

Figura 17. Plano núm. 89, Legajo 1564. Escalera del Alcázar, planta.

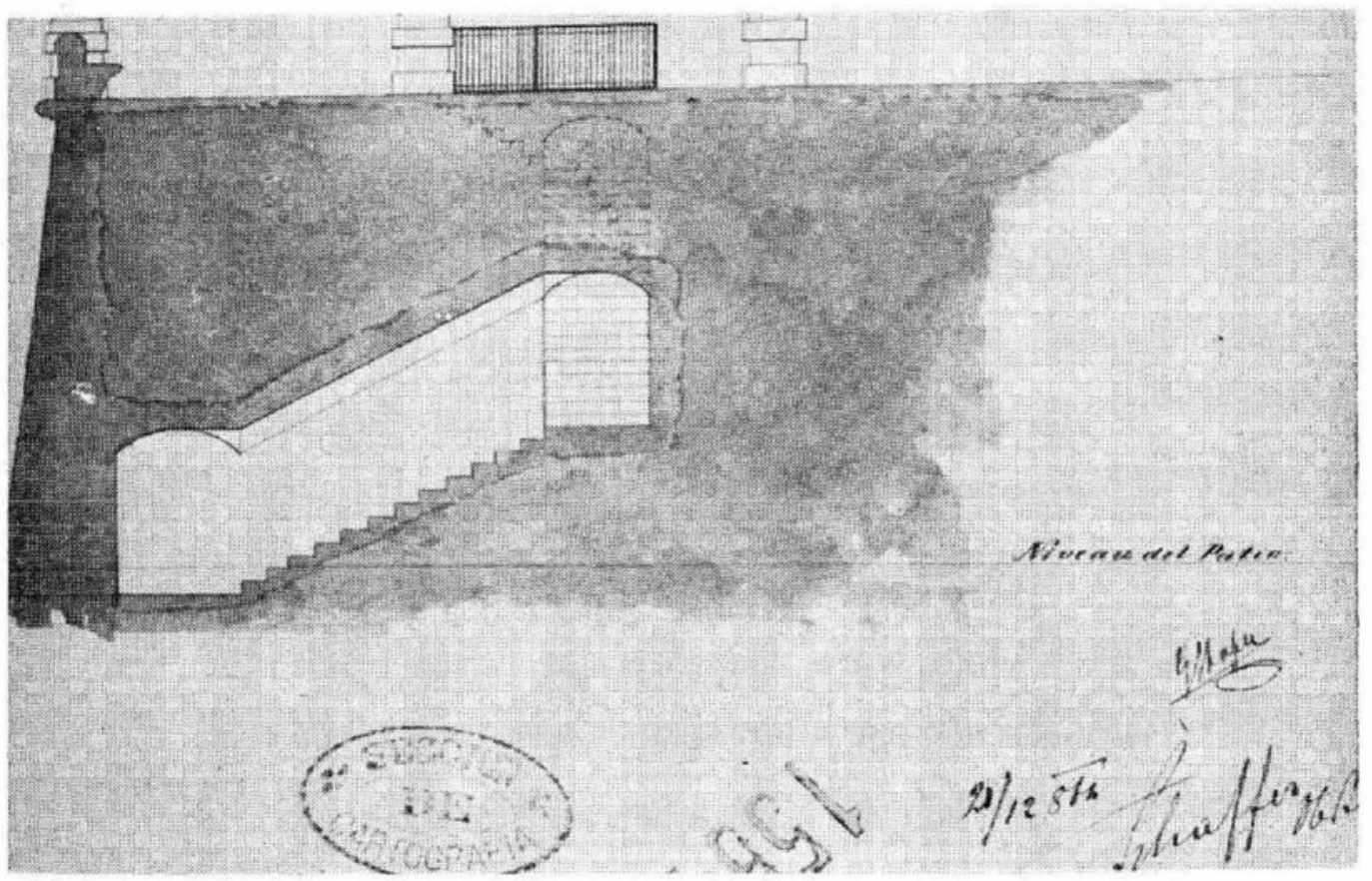

Figura 18. Plano núm. 89. Legajo 1564. Escalera del Alcázar, corte. 

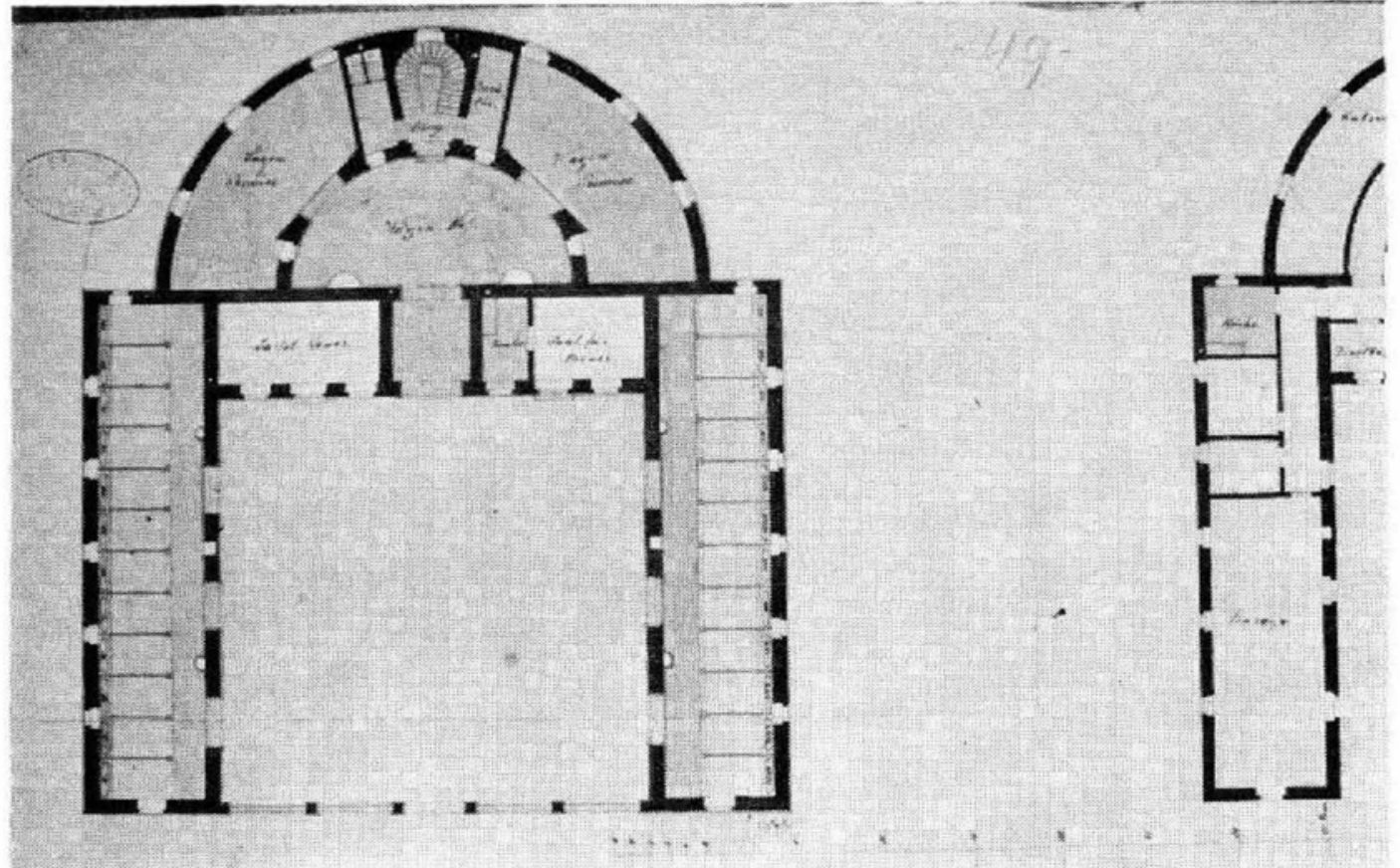

Figura 19. Plano núm. 49, Legajo 1564. Planta baja del establo.

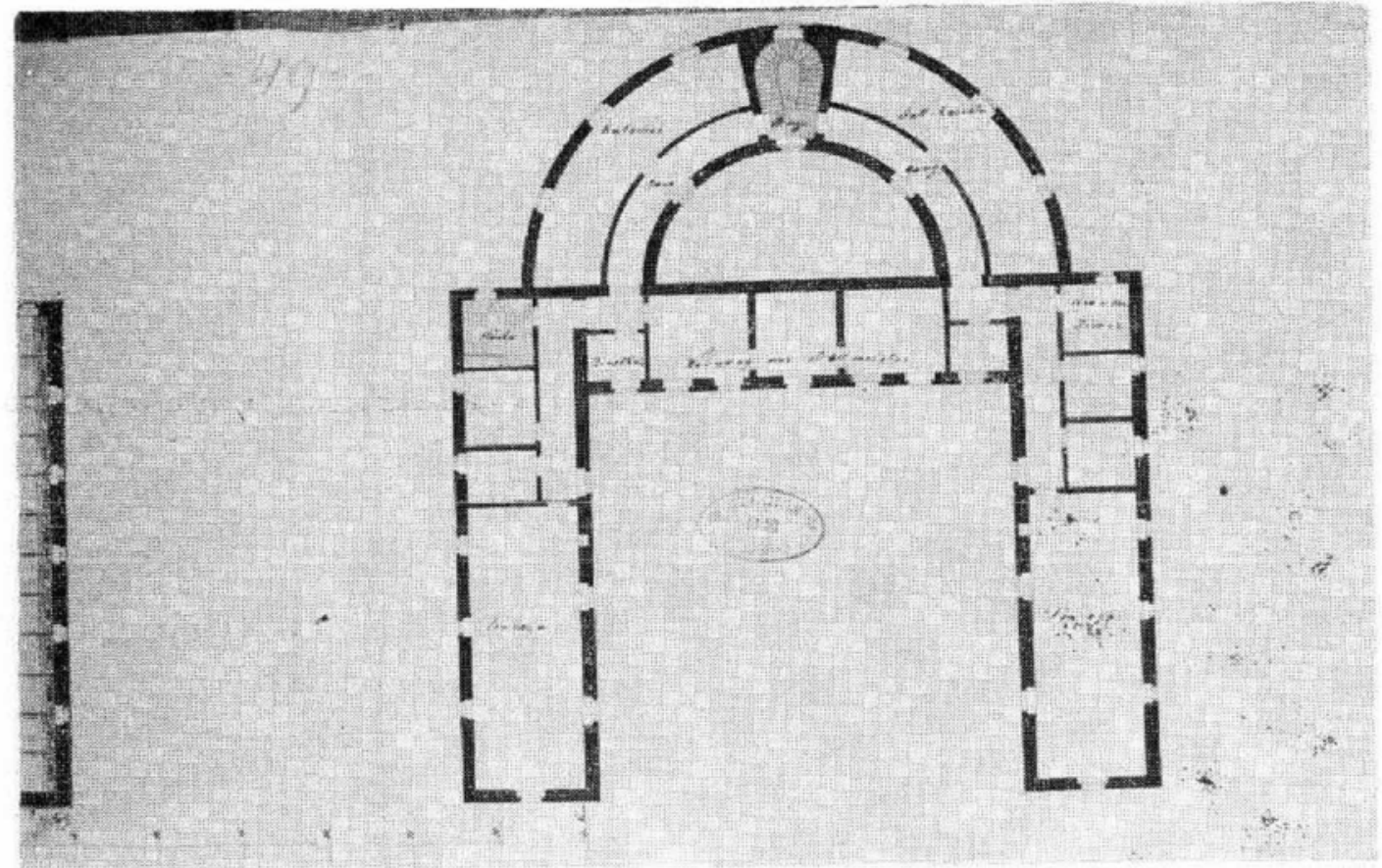

Figura 20. Plano núm. 49, Legajo 1564. Planta alta del cstablo. 


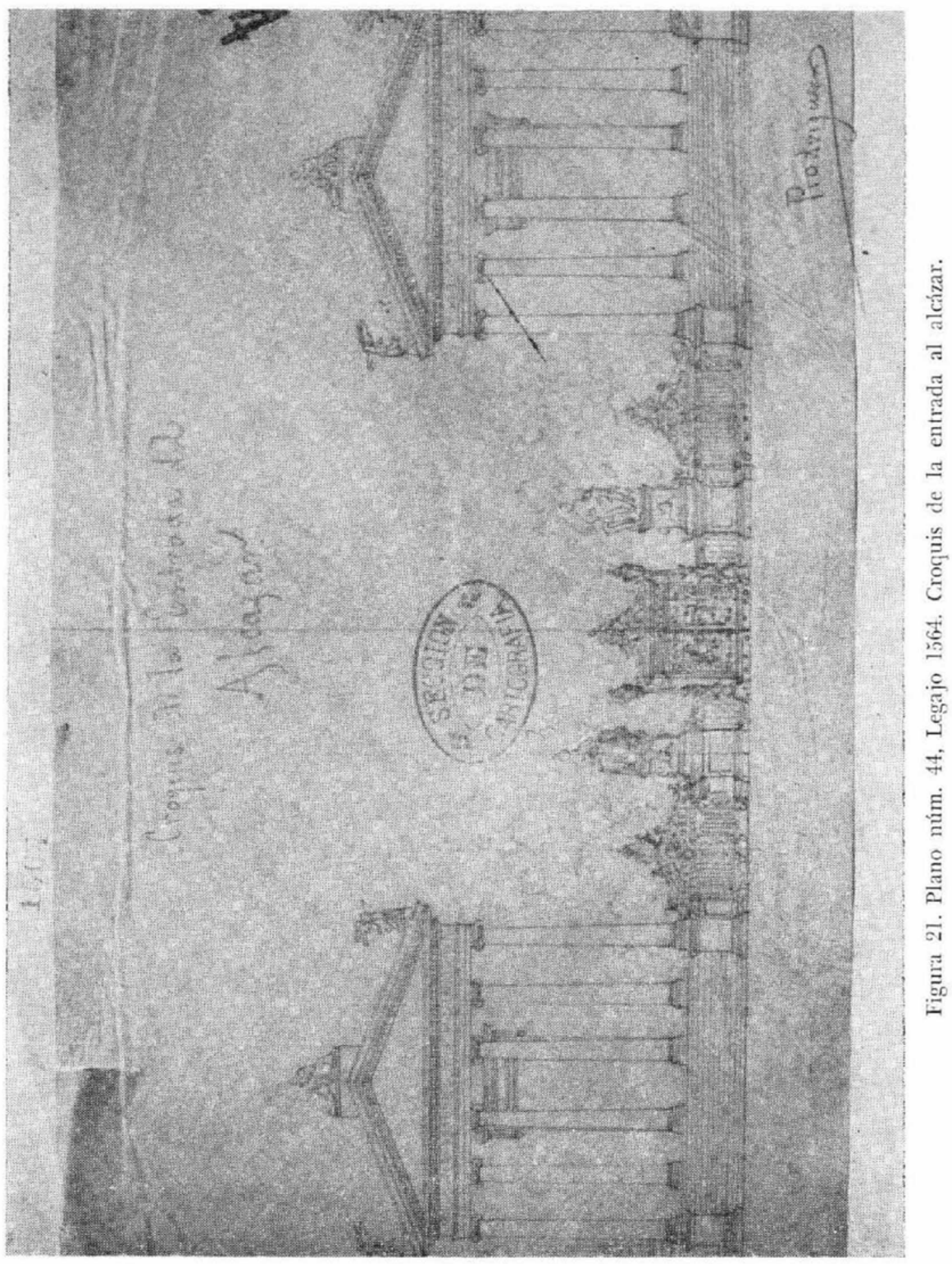


DOI: http://dx.doi.org/10.22201/iie.18703062e.1983.51.1169

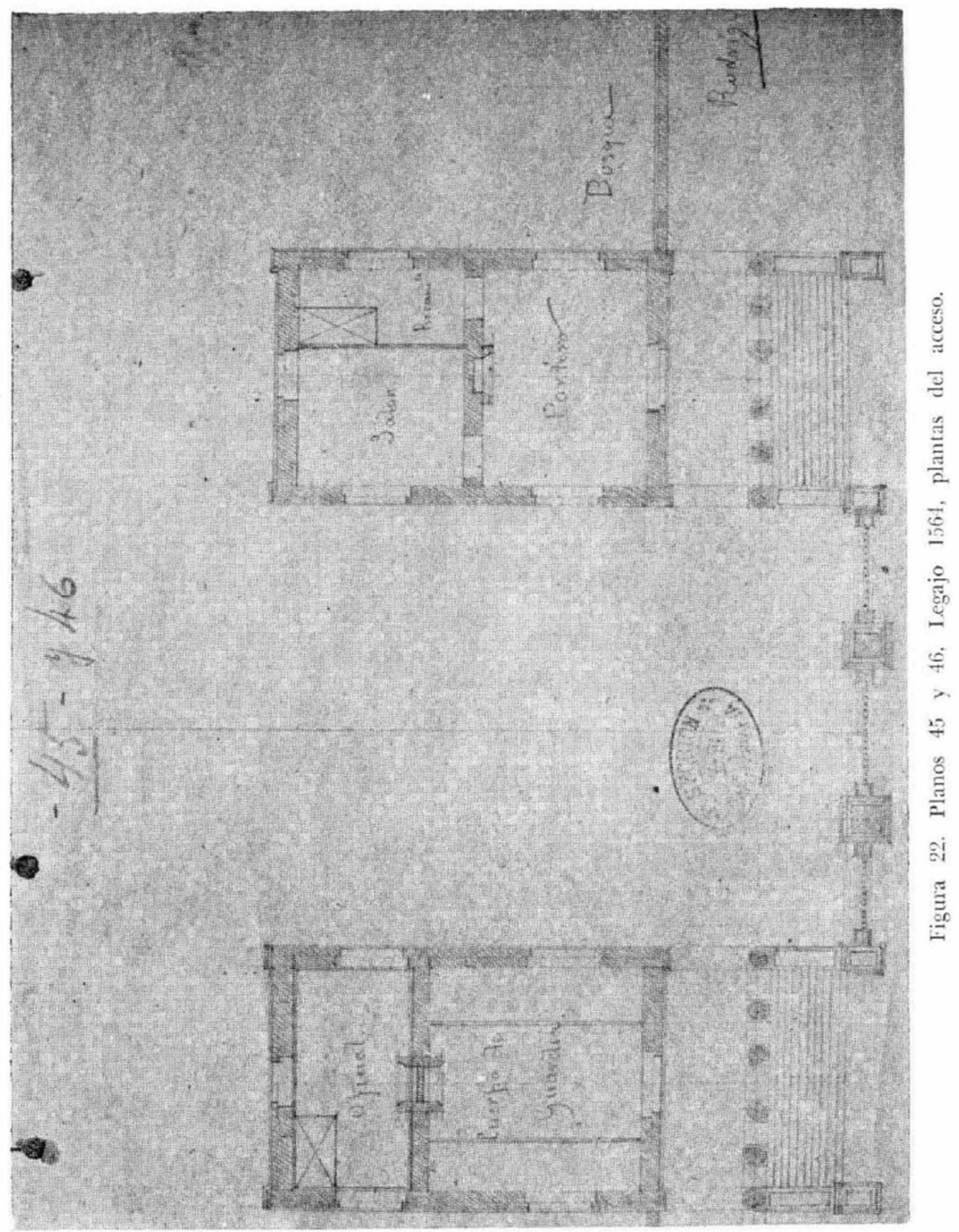


DOI: http://dx.doi.org/10.22201/iie.18703062e.1983.51.1169

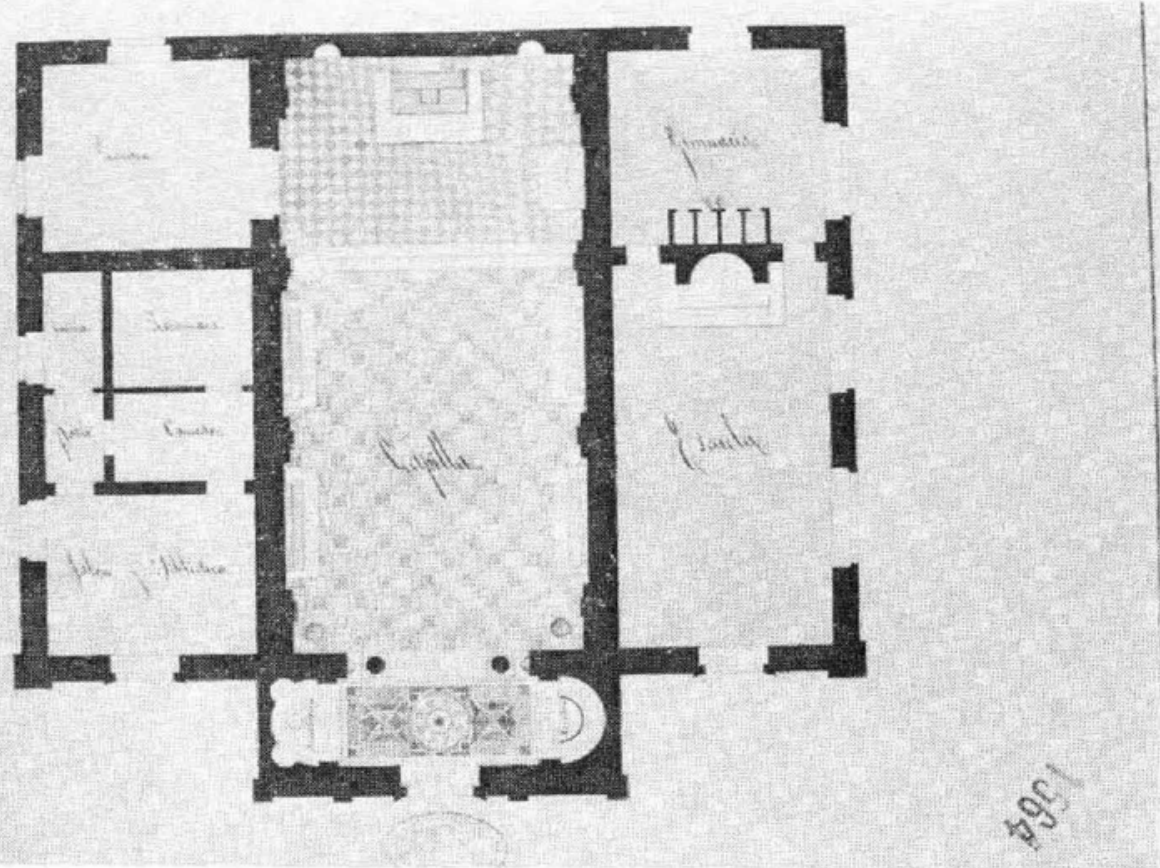

Figura 29. Plano núm. 59, Legajo 1564, planta de la capilla.

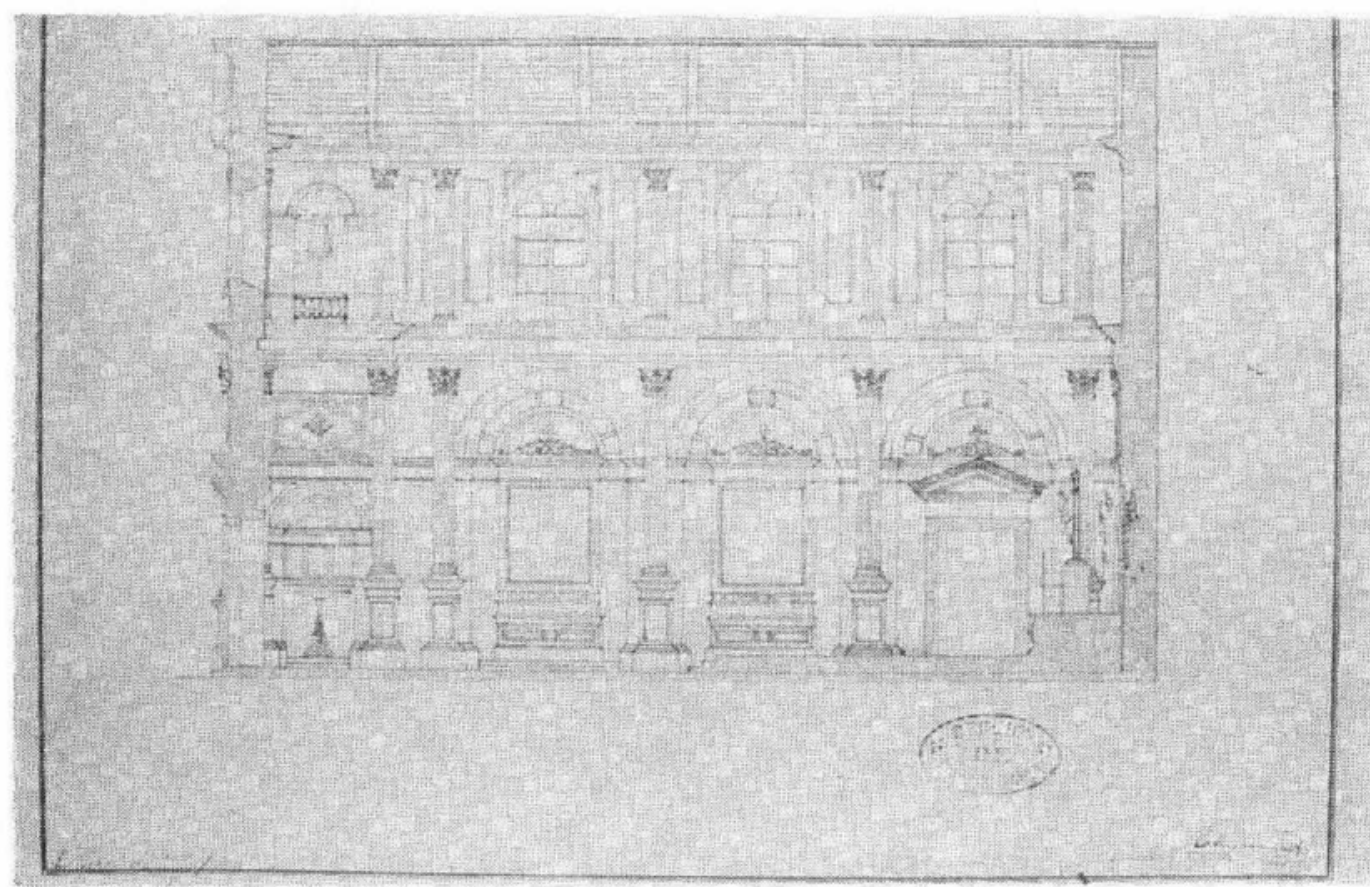

Figura 24. Plano núm. 58, Legajo 1564. Corte de la capilla. 


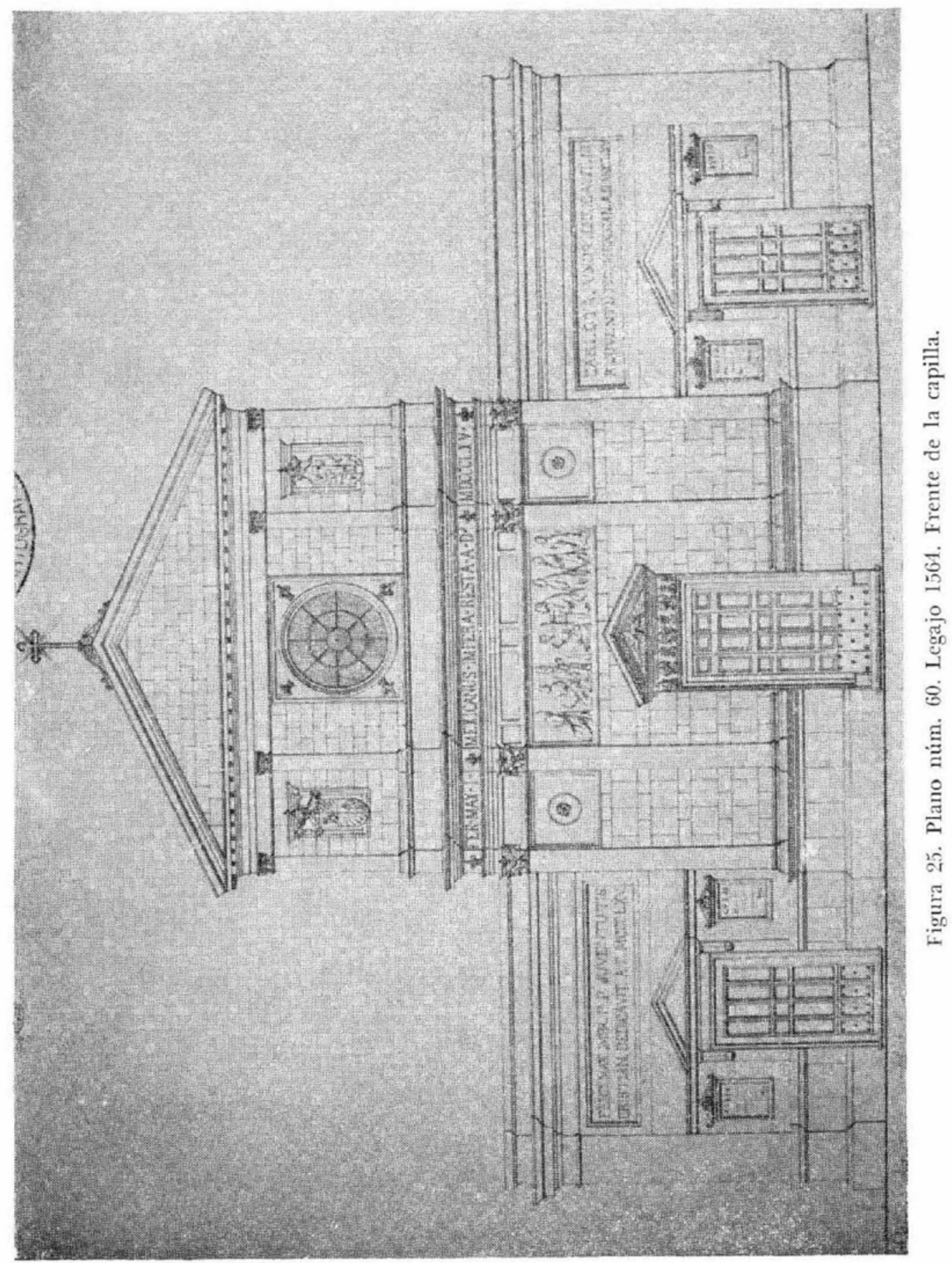


DOI: http://dx.doi.org/10.22201/iie.18703062e.1983.51.1169

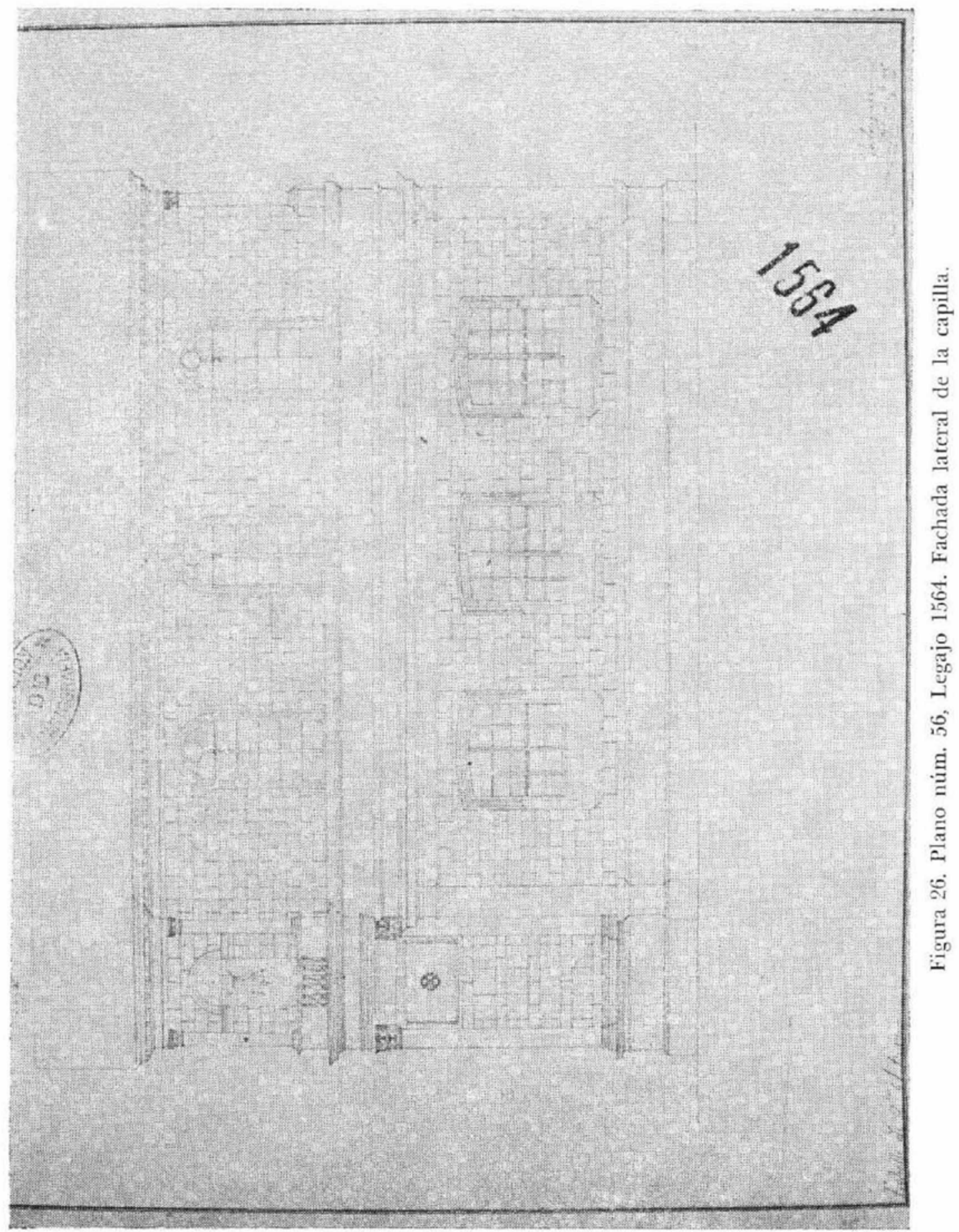


DOI: http://dx.doi.org/10.22201/iie.18703062e.1983.51.1169

Lam. II.

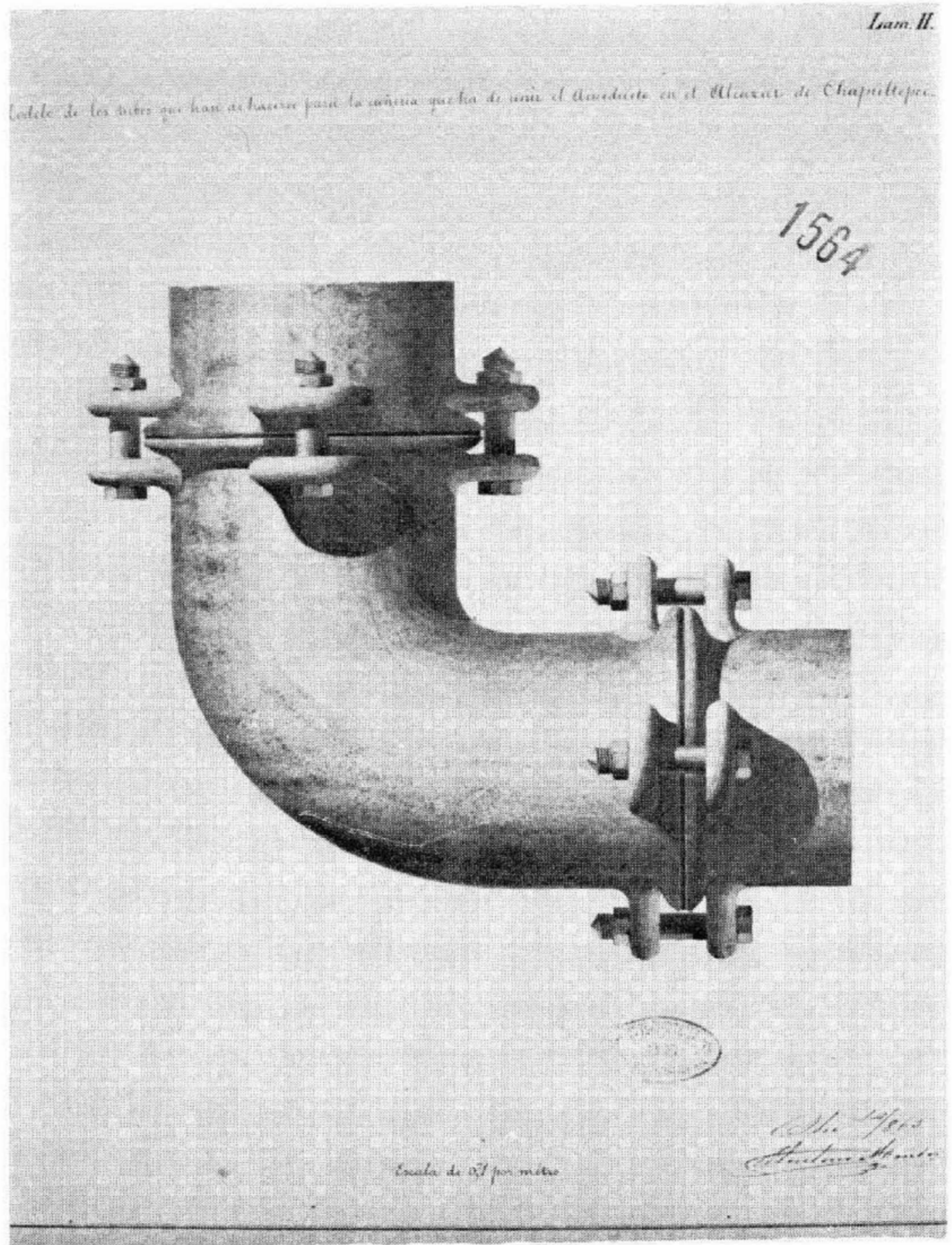

Figura 27. Plano núm. 85, Legajo 1564. Modelo de los tubos que han de hacerse para la cañería. 
DOI: http://dx.doi.org/10.22201/iie.18703062e.1983.51.1169

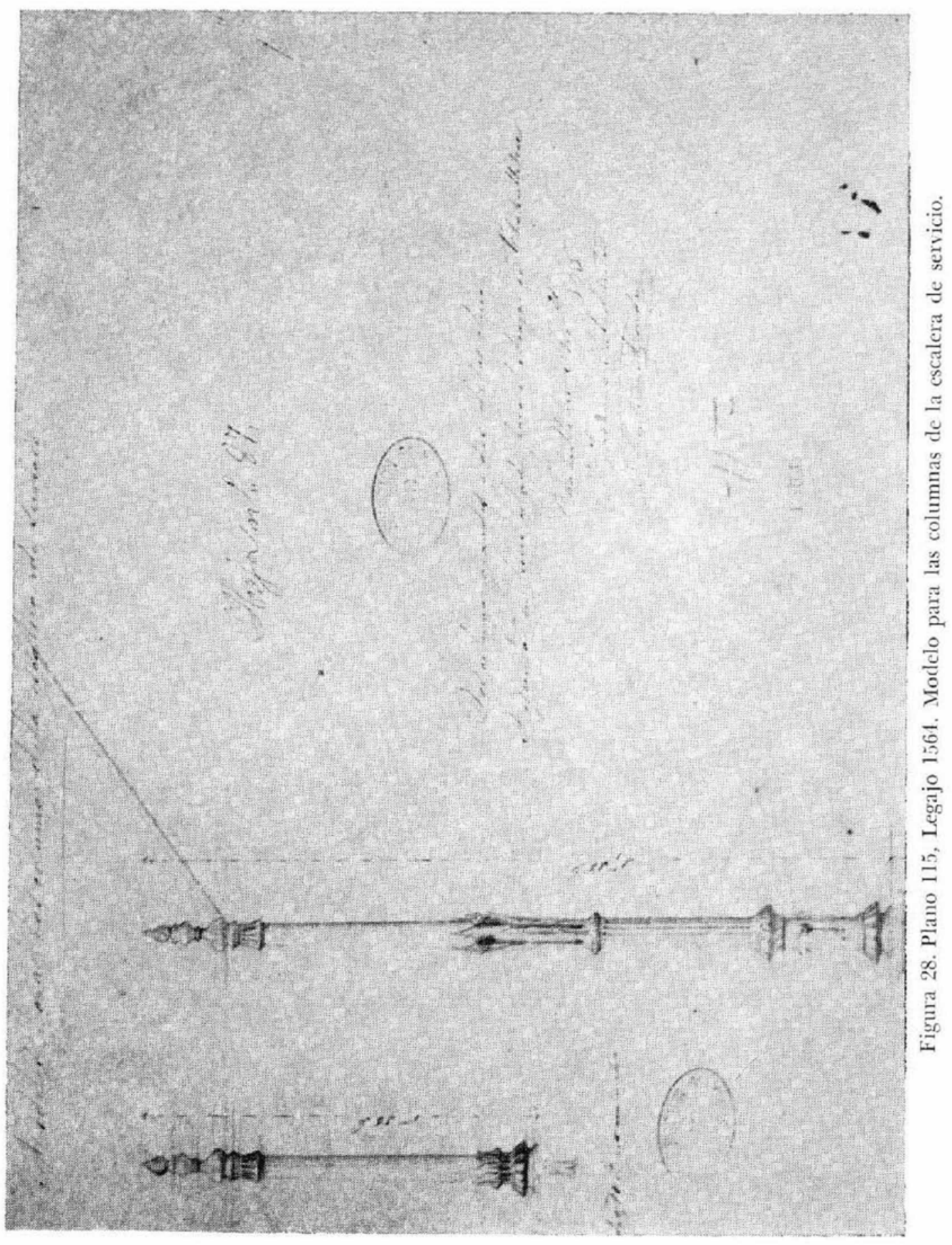


DOI: http://dx.doi.org/10.22201/iie.18703062e.1983.51.1169

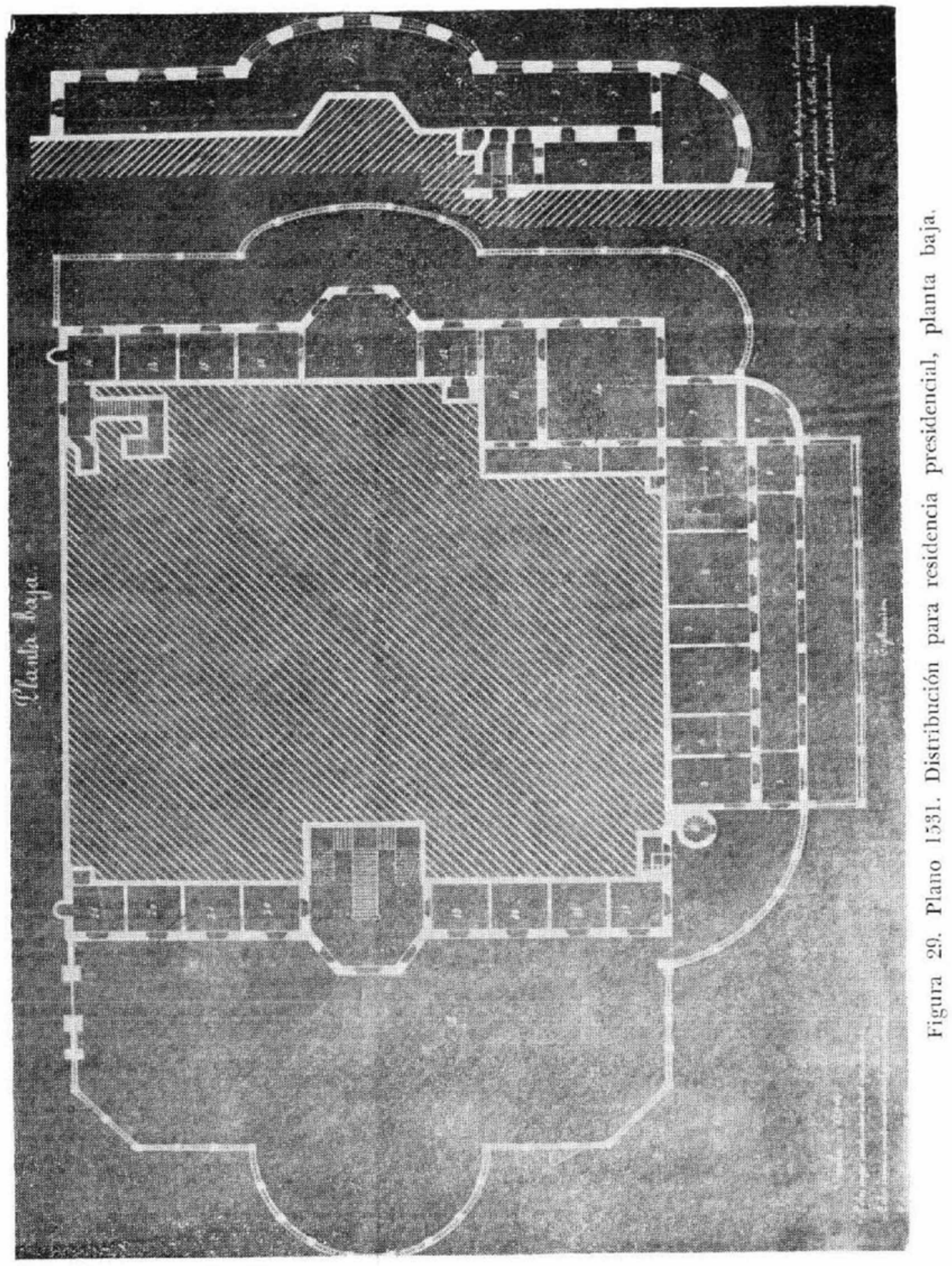


DOI: http://dx.doi.org/10.22201/iie.18703062e.1983.51.1169

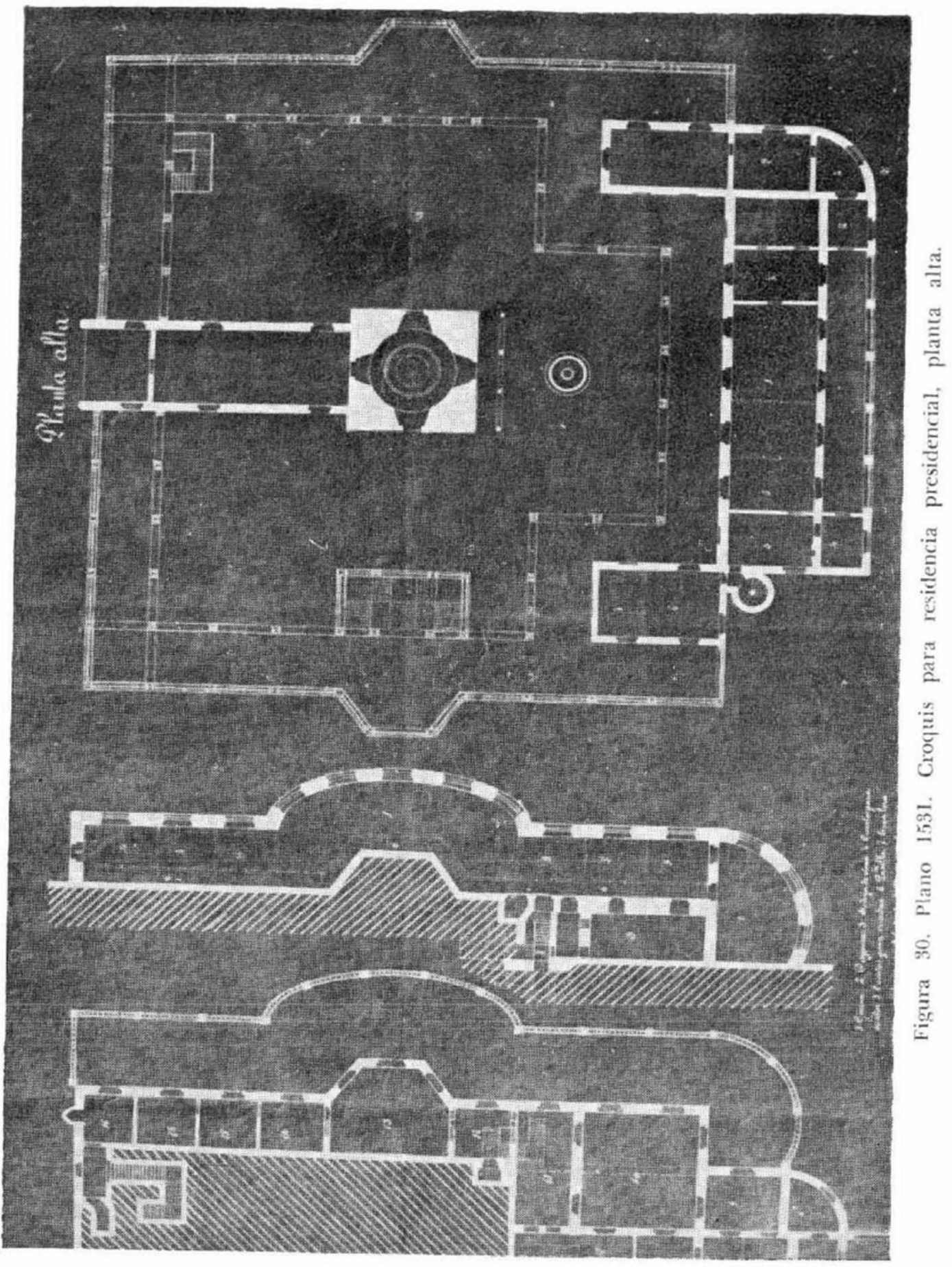


nota también en un bosquejo titulado Hauptthor der Rotonde, "Puerta principal de la rotonda", firmado C. Kaiser, del 15 de febrero de 1866 y que muestra un hemiciclo clásico, con columnas que apoyan un entablamento. 26

Parece que habia otros dos arquitectos procedentes de Austria, uno, de apellido Schaffer, quien firma un plano fechado el 20 de diciembre de 1864, de un detalle del jardin del alcázar, una escalera del parterre ${ }^{27}$ que se habia ya edificado en la época virreinal. En el corte $A-B$, se aprecia el orden toscano de los pedestales de las columnas que actualmente se conservan. el otro alarife, Schafmann, dejó el alzado de un decorado interior de pared en estilo neoclásico ecléctico. ${ }^{28}$

Un proyecto para unas caballerizas, en plantas baja y alta, con indicaciones en idioma alemán, ${ }^{29}$ no está firmado, y se dificulta, por tanto, la atribución. Los locales son los siguientes:

Wagen-Remise

Geräthe

Sattel-Kammer

Saal für Diener

Stall-Knechte

Dienstboten

Fourage

Stiege

Wagen-Hof

Küche

Kutscher

Gang

Wohnung des Stallmeisters
$=$ Cochera

$=$ Herramienta

$=$ Cuarto de sillas

= Sala de mozos

$=$ Caballerango

$=$ Mozos

$=$ Forraje

$=$ Escalera

- Patio de carros

$=$ Cocina

$=$ Cocheros

$=$ Pasillo

= Vivienda del maestro de establo

Se ven las cocheras para los carruajes, dispuestas en semicirculo alrededor de un patio de maniobras, habitaciones para la servidumbre, locales para guardar equipos y forrajes, y en dos hileras que flanquean un patio rectangular, las caballerizas con doce compartimentos a cada lado. Estos establos deberían haberse localizado pegados al muro oriente que limita el alcázar con respecto al bosque. ${ }^{30}$

\footnotetext{
26 Plano núm. 47 del legajo núm. 1564.

27 Plano núm. 34 del legajo núm. 1564.

28 Plano núm ? del legajo núm. 1564 .

29 Plano núm 49 del legajo núm 1564.

30 Jesús Romero Flores, op. cit., p. 69.
} 
Proyectos del arquitecto mexicano Ramón Rodriguez Arrangoiti: El archiduque Maximiliano se valió también de los servicios profesionales de un arquitecto mexicano, Ramón Rodríguez Arrangoiti, a quien se debe la mayor parte de la remodelación del alcázar de Chapultepec, en particular, en cuanto a lo que atañe a las construcciones erigidas en el parterre edificado en tiempos de los virreyes Bernardo y Matías de Gálvez: ${ }^{31}$

$\mathrm{El}$ archiduque Maximiliano quiso hacer de Chapultepec una residencia señorial y encargó su proyecto de reconstrucción que se cumplió casi en su totalidad y del cual se conserva intacto cuanto entonces se realizó, tanto por su valor histórico como por su valor artístico. De entonces data la distribución de la mayor parte de las habitaciones que hoy existen, así como los miradores y las terrazas desde que se contempla el paisaje..., al través del bosque de columnas en los dos pisos; los jardines aéreos, y la rampa que circunda como una gran espiral el edificio por el norte, por el oeste y el sur hasta llegar al castillo. El arquitecto que diseñó y realizó la restauración fue don Ramón Rodríguez Arrangoiti, y el decorador fue el pintor don Santiago Rebull, de quien quedan, aunque restauradas ya, las pinturas pompeyanas de los corredores, que representan danzarines.

Al igual que sus colegas austriacos, el arquitecto mexicano no se escapa de la influencia europea, sino incluso la profesa con la misma vehemencia que aquéllos, como lo manifiesta en una hoja de albanene con dibujo a lápiz bajo el título Croquis de la entrada del alcázar, con la firma: Rodríguez. ${ }^{32}$

Es uno más de esos contagios de los eternos propileos que se encuentran por docenas en las ciudades europeas, como los de Munich, construidos en 1862 por Leo von Klenze (1784-1864), o la Neve Wache de Berlín, edificada por Karl Friedrich Schinkel (1781-1841) en 1816. En el caso del arquitecto Rodríguez, se trata de dos templos jónicos hexástilos que flanquean un portón meobarroco de hierro forjado, que muy bien pudiera tenerse por una débil copia de la entrada al parque del palacio del Belvedere, de Viena. Gracias a Dios, la ciudad de México se salvó de esos minitemplos destinados no al culto de Zeus sino al alojamiento del corps du garde y de la servidumbre. En los entablamentos de los templos indicados se lee: villa suburbannemaximilia-

31 Rubén M. Campos, apud, Alfonso Teja Zabre, op. cit, pp, 134-136 32 Plano núm. 44 del legajo núm. 1564. 
NUS IMP, y en las acróteras hay unos sendos ángeles, seguramente para ser ejecutados en bronce. A este alzado corresponden las plantas en papel opaco, dibujadas a lápiz y firmadas por el mismo autor. ${ }^{33}$

También nos dejó el artista mexicano el proyecto para una capilla con sus anexos. La planta, ${ }^{34}$ dibujada a tinta china y acuarelada a colores, aunque no lleva la firma, por su correlación con el corte longitudinal, ${ }^{35}$ la fachada lateral ${ }^{36}$ y la principal, ${ }^{37}$ que sí la ostentan, la atribuyo a Rodriguez.

El edificio es de una factura neoclásica impecable, consta de tres naves, de las cuales, las laterales albergan las dependencias auxiliares, y la central, la capilla propiamente dicha. El frente de esta construcción que data de 1865, presenta en el cuerpo izquierdo la inscripción: FERD. MAX. XMPR. P. P. JUVENTUTIS CHRISTIAN. DEDICAVIT, A. D. MDCCCLXV, en el del centro, FER. MAX. I. MEXICANUS IMPERA RESTA A. D. MDCCCLXV, y en el de la derecha cARLOTA UXOR DEDICAVIT M. P. JUVENTUTIS MEXICAN. A. D. MDccclxv. Lo mismo que la idea del arquitecto Kaiser, el proyecto de su colega mexicano para la capilla del alcázar de Chapultepec tampoco llegó a realizarse.

Proyectos del ingeniero Eleuterio Méndez: De acuerdo como se expresa eil sus planos, el ingeniero Eleuterio Méndez actuó en las obras de remozamiento del castillo de Chapultepec como "Ingeniero subdirector de las obras", y de él conservamos unos planos relativos a detalles de ingeniería hidráulica, como aquel titulado: Lám. II. Modelo de los tubos que han de hacerse para la cañeria que ha de unir el acueducto en el alcázar de Chapultepec. Obre. 14 / 1865. Eleuterio Méndez. ${ }^{38}$

Del mismo modo nos dejó unos bosquejos para trabajos de fundición, como un dibujo a lápiz, ${ }^{39}$ con letrero en tinta que dice: Modelo para las columnas de la escalera de servicio. Chapultepec. Sbre. 211 1865. El ingeniero subdirector, Eleuterio Méndez y otro, un detalle de ornamentación en forma de una flor estilizada, ${ }^{40}$ acompañada de un texto a tinta: "A ejecutar en fierro colado y forjado para el Acazar

33 Planos 45 y 46 del legajo citado.

34 Plano núm. 59 del legajo núm. 1564.

35 Plano núm. 58 del legajo núm. 1564.

36 Plano núm. 56 del legajo núm. 1564

37 Plano núm. 60 del legajo núm. 1564.

38 Plano núm. 85 del legajo núm. 1564

39 Plano núm. 115 del mismo legajo.

40 Plano núm. 118 del mismo legajo. 
(sic) de Chapultepec. Chapultepec: Sbre, 20/1865. El Ingeniero Sub-Director. Eleuterio Méndez".

Proyectos posteriores a la época del imperio: Habiéndose restaurado la República, con lo que se acabó de una vez por todas con estos sueños del emperador Maximiliano y de sus arquitectos e ingenieros, no se alcanzó de inmediato la prosperidad material del país, y se restableció en el alcázar de Chapultepec por el año de 1882 el Colegio Militar. 41

Sin embargo, los progresos en la industria y el comercio favorecieron la prosperidad, y el general Porfirio Díaz logró convertir el castillo de Chapultepec en una residencia de lujo con mayor éxito que el virrey Gálvez y el archiduque Maximiliano. ${ }^{42}$ El presidente Benito Juárez nunca residió en el castillo, y Sebastián Lerdo de Tejada lo hizo ocasionalmente. ${ }^{43}$

De esta adaptación a residencia presidencial sé conserva la copia heliográfica de un plano ${ }^{44}$ que se refiere al parterre de la época colonial, modificado en la de Maximiliano, lo que nos hace suponer que el Colegio Militar se alojaba en el palacio virreinal. El plano lleva por título Palacio de Chapultepec. Croquis de la distribución para residencia presidencial. Lo firma Juan N. Anza en agosto de 1882, y lo calca José Ortega y Espinosa en octubre del mismo año. Muestra las plantas baja y alta de las construcciones erigidas sobre el parterve jardinado, y se advierte la posición del caballero alto, y se reconoce la distribución de los locales.

A la mayoría de estos proyectos comentados, les es propio cierto aire de sueño; son engendros fantásticos que manifiestan en el campo de las artes plásticas la fallida aventura de establecer desde la lejana Furopa un imperio en México, una hazaña que con justa razón puede relegarse al país de los sueños, en vista de lo anacrónico del intento, ya que se trataba de implantar formas de vida ajenas a la realidad nacional, y un modo de gobernar que ya no era el adecuado en una época, en la cual iba consolidándose la democracia liberal y republicana.

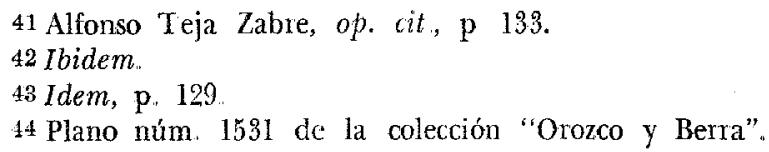

